\title{
High organic inputs explain shallow and deep SOC storage in a long-term agroforestry system - combining experimental and modeling approaches
}

\author{
Rémi Cardinael $^{1,2,3,4}$, Bertrand Guenet ${ }^{5}$, Tiphaine Chevallier ${ }^{1}$, Christian Dupraz ${ }^{6}$, Thomas Cozzi ${ }^{2}$, and Claire Chenu ${ }^{2}$ \\ ${ }^{1}$ Eco\&Sols, IRD, CIRAD, INRA, Montpellier SupAgro, Univ. Montpellier, Montpellier, France \\ ${ }^{2}$ AgroParisTech, UMR Ecosys, Avenue Lucien Brétignières, 78850 Thiverval-Grignon, France \\ ${ }^{3}$ CIRAD, UPR AIDA, 34398 Montpellier, France \\ ${ }^{4}$ AIDA, Univ Montpellier, CIRAD, Montpellier, France \\ ${ }^{5}$ Laboratoire des Sciences du Climat et de l'Environnement, UMR CEA-CNRS-UVSQ, CE L'Orme des Merisiers, \\ 91191 Gif-Sur-Yvette, France \\ ${ }^{6}$ System, INRA, CIRAD, Montpellier SupAgro, Univ. Montpellier, Montpellier, France
}

Correspondence: Rémi Cardinael (remi.cardinael@ cirad.fr)

Received: 4 April 2017 - Discussion started: 12 April 2017

Revised: 1 December 2017 - Accepted: 4 December 2017 - Published: 15 January 2018

\begin{abstract}
Agroforestry is an increasingly popular farming system enabling agricultural diversification and providing several ecosystem services. In agroforestry systems, soil organic carbon (SOC) stocks are generally increased, but it is difficult to disentangle the different factors responsible for this storage. Organic carbon (OC) inputs to the soil may be larger, but SOC decomposition rates may be modified owing to microclimate, physical protection, or priming effect from roots, especially at depth. We used an 18-year-old silvoarable system associating hybrid walnut trees (Juglans regia $\times$ nigra) and durum wheat (Triticum turgidum L. subsp. durum) and an adjacent agricultural control plot to quantify all OC inputs to the soil - leaf litter, tree fine root senescence, crop residues, and tree row herbaceous vegetation - and measured SOC stocks down to $2 \mathrm{~m}$ of depth at varying distances from the trees. We then proposed a model that simulates SOC dynamics in agroforestry accounting for both the whole soil profile and the lateral spatial heterogeneity. The model was calibrated to the control plot only.

Measured OC inputs to soil were increased by about $40 \%$ ( $+1.11 \mathrm{tCha}^{-1} \mathrm{yr}^{-1}$ ) down to $2 \mathrm{~m}$ of depth in the agroforestry plot compared to the control, resulting in an additional SOC stock of $6.3 \mathrm{tCha}^{-1}$ down to $1 \mathrm{~m}$ of depth. However, most of the SOC storage occurred in the first $30 \mathrm{~cm}$ of soil and in the tree rows. The model was strongly validated, properly describing the measured SOC stocks and
\end{abstract}

distribution with depth in agroforestry tree rows and alleys. It showed that the increased inputs of fresh biomass to soil explained the observed additional SOC storage in the agroforestry plot. Moreover, only a priming effect variant of the model was able to capture the depth distribution of SOC stocks, suggesting the priming effect as a possible mechanism driving deep SOC dynamics. This result questions the potential of soils to store large amounts of carbon, especially at depth. Deep-rooted trees modify OC inputs to soil, a process that deserves further study given its potential effects on SOC dynamics.

\section{Introduction}

Agroforestry systems are complex agroecosystems combining trees and crops or pastures within the same field (Nair, 1985, 1993; Somarriba, 1992). More precisely, silvoarable systems associate parallel tree rows with annual crops. Some studies showed that these systems could be very productive, with a land equivalent ratio (Mead and Willey, 1980) reaching up to 1.3 (Graves et al., 2007). Silvoarable systems may therefore produce up to $30 \%$ more marketable biomass on the same area of land compared to crops and trees grown separately. This performance can be explained by a better use 
of water, nutrients, and light by the agroecosystem throughout the year. Trees grown in silvoarable systems usually grow faster than the same trees grown in forest ecosystems because of their lower density and because they also benefit from crop fertilization (Balandier and Dupraz, 1999; Chaudhry et al., 2003; Chifflot et al., 2006). In temperate regions, farmers usually grow one crop per year, and this association of trees can extend the growing period on the field scale, especially when winter crops are intercropped with trees having a late bud break (Burgess et al., 2004). However, after several years, a decrease in crop yield can be observed in mature and highly dense plantations, especially close to the trees, due to competition between crops and trees for light, water, and nutrients (Burgess et al., 2004; Dufour et al., 2013; Yin and He, 1997).

Part of the additional biomass produced in agroforestry is used for economical purposes, such as timber or fruit production. Leaves, tree fine roots, pruning residues, and the herbaceous vegetation growing in the tree rows will usually return to the soil, contributing to a higher input of organic carbon (OC) to the soil compared to an agricultural field (Peichl et al., 2006).

In such systems, the observed soil organic carbon (SOC) stocks are also generally higher compared to cropland (Albrecht and Kandji, 2003; Kim et al., 2016; Lorenz and Lal, 2014). Cardinael et al. (2017) measured a mean SOC stock accumulation rate of $0.24(0.09-0.46) \mathrm{tCha}^{-1} \mathrm{yr}^{-1}$ at 0 $30 \mathrm{~cm}$ of depth in several silvoarable systems compared to agricultural plots in France. Higher SOC stocks were also found in Canadian agroforestry systems, but measured only to $20 \mathrm{~cm}$ of depth (Bambrick et al., 2010; Oelbermann et al., 2004; Peichl et al., 2006).

To our knowledge, we are still not able to disentangle the factors responsible for such a higher SOC storage. This SOC storage might be due to higher OC inputs, but it could also be favored by a modification of the SOC decomposition owing to a change in SOC physical protection (Haile et al., 2010) and/or in soil temperature and moisture.

The introduction of trees in an agricultural field modifies the amount, but also the distribution, of fresh organic carbon (FOC) input to the soil both vertically and horizontally (Bambrick et al., 2010; Howlett et al., 2011; Peichl et al., 2006). FOC inputs from the trees decrease with increasing distance from the trunk and with soil depth (Moreno et al., 2005). In contrast, crop yield usually increases with increasing distance from the trees (Dufour et al., 2013; Li et al., 2008). Therefore, the proportions of FOC coming from both the crop residues and the trees change with distance from the trees, soil depth, and time.

Tree fine roots (diameter $\leq 2 \mathrm{~mm}$ ) are the most active part of root systems (Eissenstat and Yanai, 1997) and play a major role in carbon cycling. In silvoarable systems, tree fine root distribution within the soil profile is strongly modified due to competition with the crop, inducing a deeper rooting compared to trees grown in forest ecosystems (Cardinael et al., 2015a; Mulia and Dupraz, 2006). Deep soil layers may therefore receive significant $\mathrm{OC}$ inputs from fine root mortality and exudates. Root carbon has a higher mean residence time in the soil compared to shoot carbon (Kätterer et al., 2011; Rasse et al., 2006), presumably because root residues are preferentially stabilized within microaggregates or adsorbed to clay particles. Moreover, temperature and moisture conditions are more buffered in the subsoil than in the topsoil. The microbial biomass is also smaller at depth (Eilers et al., 2012; Fierer et al., 2003), and the spatial segregation with organic matter is larger (Salomé et al., 2010), resulting in lower decomposition rates. Deep root carbon input in the soil could therefore contribute to SOC storage with high mean residence times. However, some studies showed that adding FOC - a source of energy for microorganisms - to the subsoil enhanced the decomposition of stabilized carbon, a process called the "priming effect" (Fontaine et al., 2007). The priming effect is stronger when induced by labile molecules like root exudates than by root litter coming from the decomposition of dead roots (Shahzad et al., 2015). Therefore, the net effect of deep roots on SOC stocks has to be assessed, especially in silvoarable systems.

Models are crucial as they allow virtual experiments to best design and understand complex processes in these systems (Luedeling et al., 2016). Several models have been developed to simulate interactions for light, water, and nutrients between trees and crops (Charbonnier et al., 2013; Duursma and Medlyn, 2012; van Noordwijk and Lusiana, 1999; Talbot, 2011) or to predict tree growth and crop yield in agroforestry systems (Graves et al., 2010; van der Werf et al., 2007). However, none of these models are designed to simulate SOC dynamics in agroforestry systems and they are therefore not useful to estimate SOC storage. Oelbermann and Voroney (2011) evaluated the ability of the CENTURY model (Parton et al., 1987) to predict SOC stocks in tropical and temperate agroforestry systems, but with a singlelayer modeling approach $(0-20 \mathrm{~cm})$. The approach of modeling a single topsoil layer assumes that deep SOC does not play an active role in carbon cycling, while it was shown that deep soil layers contain important amounts of SOC (Jobbagy and Jackson, 2000) and that part of this deep SOC could cycle on decadal timescales due to root inputs or dissolved organic carbon transport (Baisden and Parfitt, 2007; Koarashi et al., 2012). The need to take into account deep soil layers when modeling SOC dynamics is now well recognized in the scientific community (Baisden et al., 2002; Elzein and Balesdent, 1995), and several models have been proposed (Braakhekke et al., 2011; Guenet et al., 2013; Koven et al., 2013; Taghizadeh-Toosi et al., 2014; Ahrens et al., 2015). Using vertically discretized soils is particularly important when modeling the impact of agroforestry systems on SOC stocks, but to our knowledge, vertically spatialized SOC models have not yet been tested for these systems.

The aims of this study were then twofold: (i) to propose a model of soil $\mathrm{C}$ dynamics in agroforestry systems 
able to account for both vertical and lateral spatial heterogeneities and (ii) to test whether variations in fresh organic carbon (FOC) input could explain increased SOC stocks both using experimental data and model runs.

For this, we first compiled data on FOC inputs to the soil obtained in an 18-year-old agroforestry plot and in an agricultural control plot in southern France, in which SOC stocks have been recently quantified to $2 \mathrm{~m}$ of depth (Cardinael et al., 2015b). FOC inputs comprised tree fine roots, tree leaf litter, and aboveground and belowground biomass of the crop and of the herbaceous vegetation in the tree rows. We compiled recently published data for FOC inputs (Cardinael et al., 2015a; Germon et al., 2016) and measured the others (Table 1).

We then modified a two-pool model proposed by Guenet et al. (2013) to create a spatialized model over depth and distance from the tree, the CARBOSAF model (soil organic CARBOn dynamics in Silvoarable AgroForestry systems). Based on data acquired since the tree planting in 1995 (crop yield, tree growth) and on FOC inputs, we modeled SOC dynamics to $2 \mathrm{~m}$ of depth in both the silvoarable and agricultural control plot. We evaluated the model against measured SOC stocks along the profile and used this opportunity to test the importance of the priming effect (PE) for deep soil C dynamics in a silvoarable system. The performance of the twopool model including PE was also compared with a model version including three OC pools.

\section{Materials and methods}

\subsection{Study site}

The experimental site is located at the Restinclières Estate in Prades-le-Lez, $15 \mathrm{~km}$ north of Montpellier, France (longitude $04^{\circ} 01^{\prime} \mathrm{E}$, latitude $43^{\circ} 43^{\prime} \mathrm{N}$, elevation $54 \mathrm{~m}$ a.s.l.). The climate is subhumid Mediterranean with an average temperature of $15.4^{\circ} \mathrm{C}$ and an average annual rainfall of $973 \mathrm{~mm}$ (years 1995-2013). The soil is a silty and carbonated $(\mathrm{pH}=8.2)$ deep alluvial Fluvisol (IUSS Working Group WRB, 2007). In February 1995, a 4.6 ha silvoarable agroforestry plot was established with the planting of hybrid walnut trees (Juglans regia $\times$ nigra $\mathrm{cv} . \mathrm{NG} 23$ ) at a density of 192 treesha $^{-1}$ but later thinned to 110 trees ha $^{-1}$. Trees were planted at $13 \mathrm{~m} \times 4 \mathrm{~m}$ spacing, and tree rows are eastwest oriented. The cultivated alleys are $11 \mathrm{~m}$ wide. The remaining part of the plot (1.4 ha) was kept as an agricultural control plot. Since the tree planting, the agroforestry alleys and the control plot have been managed in the same way. The associated crop is durum wheat most of the time (Triticum turgidum L. subsp. durum), except in 1998, 2001, and 2006 when rapeseed (Brassica napus L.) was cultivated and in 2010, and 2013 when pea (Pisum sativum L.) was cultivated. The soil is ploughed to a depth of $0.2 \mathrm{~m}$ before sowing, and the wheat crop is fertilized with an average of

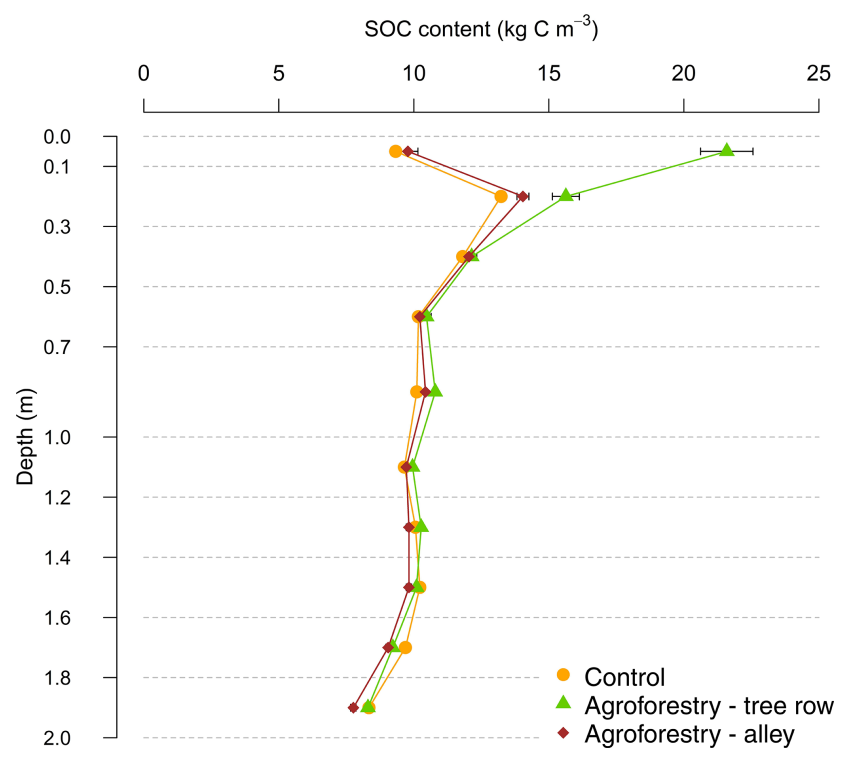

Figure 1. Soil organic carbon content in both the agroforestry and agricultural control plot. Associated errors are standard errors. $N=$ 93 in the control, $N=40$ in the agroforestry tree row, $N=60$ in the agroforestry alley. Data from Cardinael et al. (2015b).

$120 \mathrm{~kg} \mathrm{Nha}^{-1} \mathrm{yr}^{-1}$. Crop residues (wheat straw) are also exported, but about $25 \%$ remains on the soil. Tree rows are covered by spontaneous herbaceous vegetation. Two successive herbaceous vegetation types occur during the year, one in summer and one in winter. The summer vegetation is mainly composed of Avena fatua $\mathrm{L}$. and is $1.5 \mathrm{~m}$ tall. In winter, the vegetation is a mix of Achillea millefolium L., Galium aparine L., Vicia L., Ornithogalum umbellatum L., and Avena fatua $\mathrm{L}$. and is $0.2 \mathrm{~m}$ tall.

\subsection{Organic carbon stocks}

\subsubsection{Soil organic carbon stocks}

SOC data have been published in Cardinael et al. (2015b; Fig. 1). Briefly, soil cores were sampled down to $2 \mathrm{~m}$ of depth in May 2013, 100 in the agroforestry plot, and 93 in the agricultural control plot. SOC concentrations, soil bulk densities, SOC stocks, and soil texture were measured for 10 soil layers $(0.0-0.1,0.1-0.3,0.3-0.5,0.5-0.7,0.7-1.0,1.0-1.2$, $1.2-1.4,1.4-1.6,1.6-1.8$, and $1.8-2.0 \mathrm{~m}$ ). In the agroforestry plot, 40 soil cores were taken in the tree rows, while 60 were sampled in the alleys at varying distances from the trees. Soil organic carbon stocks were quantified on an equivalent soil mass basis (Ellert and Bettany, 1995). 
Table 1. Synthesis of the different field and laboratory data available or measured and their sources.

\begin{tabular}{ll}
\hline Description of the data & Source \\
\hline Soil texture, bulk densities, SOC stocks & Cardinael et al. (2015b) \\
Soil temperature and soil moisture & Measured \\
Tree growth (DBH) & Measured \\
Tree wood density & Talbot (2011) \\
Tree fine root biomass & Cardinael et al. (2015a) \\
Tree fine root turnover & Germon et al. (2016) \\
Crop yield and crop ABG biomass & Dufour et al. (2013) and measured \\
Crop root biomass & Prieto et al. (2015) and measured \\
Tree row herbaceous vegetation - ABG biomass & Measured \\
Tree row herbaceous vegetation - root biomass & Measured \\
Biomass carbon concentrations & Measured \\
Potential decomposition rate of roots & Prieto et al. (2016) \\
HSOC potential decomposition rate & Measured \\
\hline
\end{tabular}

DBH: diameter at breast height; ABG: aboveground; OC: organic carbon; HSOC: humified soil organic carbon.

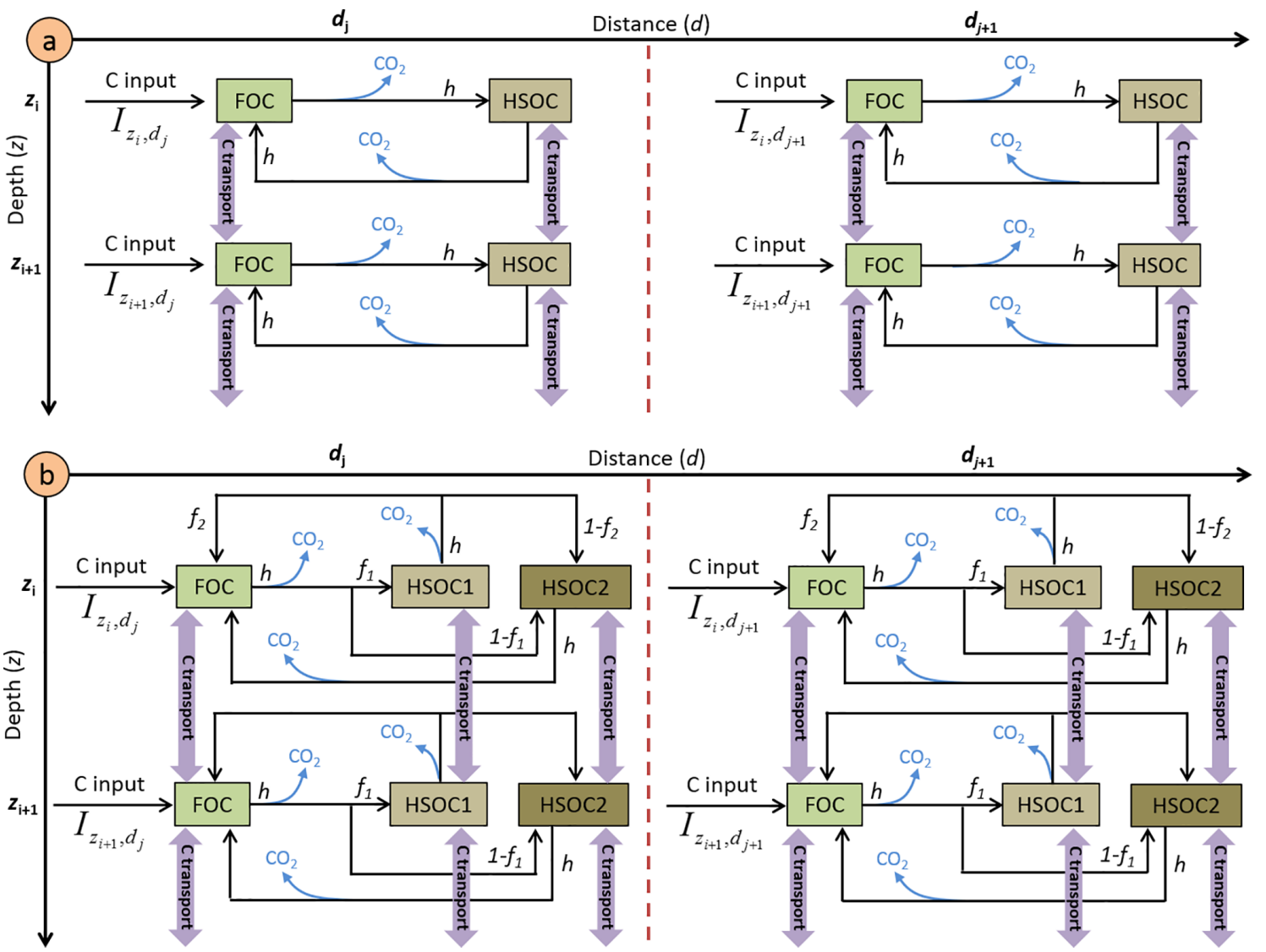

Figure 2. Schematic representation of the pools and the fluxes of the (a) two-pool model and (b) three-pool model.

\subsubsection{Tree aboveground and stump carbon stocks}

Three hybrid walnuts were chopped down in 2012. The trunk circumference was measured every meter up to the maximum height of the tree to estimate its volume. The trunk biomass was estimated by multiplying the trunk volume by the wood density that was measured at $616 \mathrm{~kg} \mathrm{~m}^{-3}$ during previous work at the same site (Talbot, 2011). Then, branches were cut, the stump was uprooted, and they were weighted separately. Samples were brought to the laboratory to determine the moisture content, which enabled the calculation of the branch and the stump dry mass. 


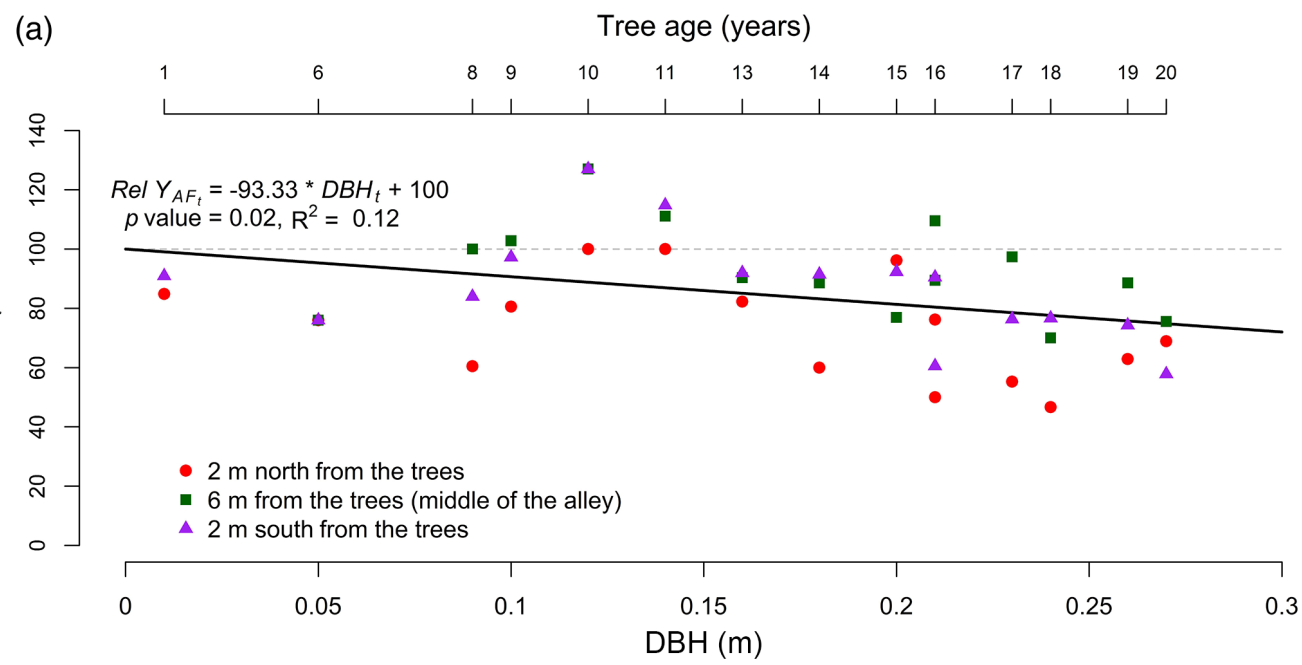

(b)

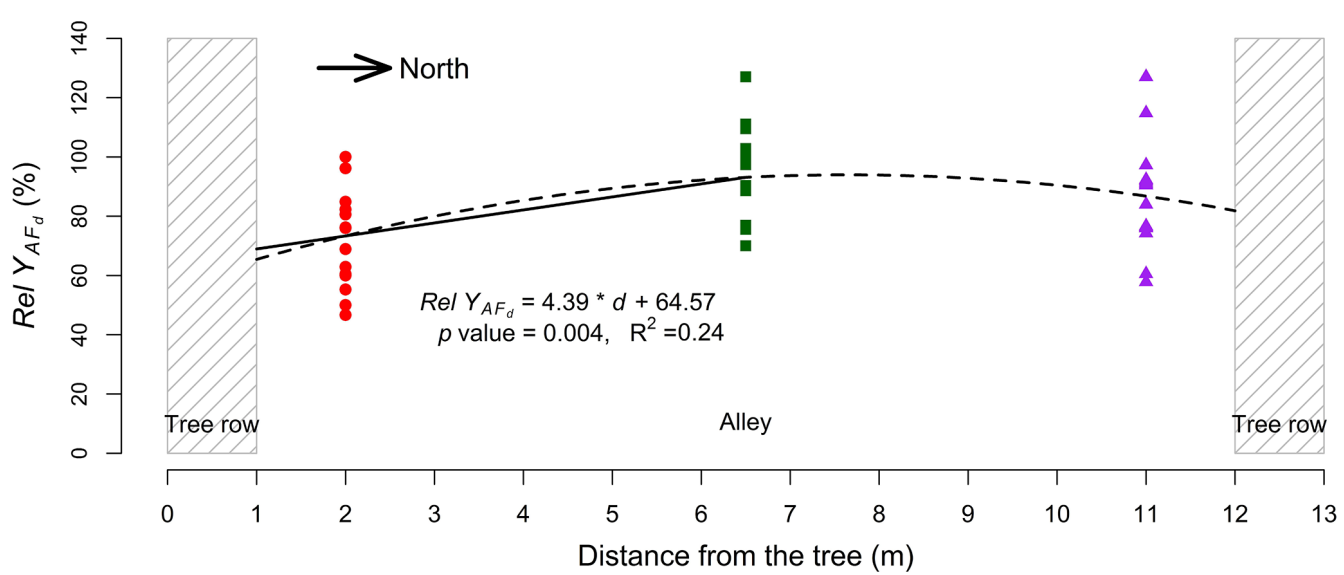

Figure 3. (a) Relative yield $\left(\operatorname{Rel} Y_{\mathrm{AF}_{t}}\right)$ in the agroforestry plot compared to the control plot as a function of tree growth, represented by the diameter at breast height $(\mathrm{DBH})$ at year $t$. (b) Relative yield $\left(Y_{\mathrm{AF}_{t, d}}\right)$ as a function of the distance from the tree.

\subsection{Measurements of organic carbon inputs in the field}

\subsubsection{Carbon inputs from tree fine root mortality}

The tree fine root (diameter $\leq 2 \mathrm{~mm}$ ) biomass was quantified and coupled with an estimate of the tree fine root turnover in order to predict the carbon input to the soil from the tree fine root mortality. A detailed description of the methods used to estimate the tree fine root biomass can be found in Cardinael et al. (2015a). In March 2012, a 5 (length) $\times 1.5$ (width) $\times 4 \mathrm{~m}$ (depth) pit was open in the agroforestry plot perpendicular to the tree row north of the trees. The tree fine root distribution was mapped down to $4 \mathrm{~m}$ of depth, and the tree fine root biomass was quantified in the tree row and in the alley. Only results concerning the first $2 \mathrm{~m}$ of soil, among those obtained by Cardinael et al. (2015a), will be used here.
In July 2012, 16 minirhizotrons were installed in the agroforestry pit at $0,1,2.5$, and $4 \mathrm{~m}$ of depth and at 2 and $5 \mathrm{~m}$ from the trees. The tree root growth and mortality were monitored during 1 year using a scanner (CI-600 Root Growth Monitoring System; CID, USA) and analyzed using the WinRHIZO Tron software (Régent, Canada). A detailed description of the methods and the results used to estimate the tree fine root turnover can be found in Germon et al. (2016).

\subsubsection{Tree litterfall}

In 2009, the crowns of two walnut trees were packed with a net in order to collect the leaf biomass from September to January. The same was done in 2012 with three other walnut trees. The leaf litter was then dried, weighted, and analyzed for $\mathrm{C}$ to quantify the leaf carbon input per tree. 


\subsubsection{Aboveground and belowground input from the crop}

Since the tree planting in 1995, the crop yield was measured 14 times (in 1995, 2000, 2002, 2003, 2004, 2005, 2007, 2008, 2009, 2010, 2011, 2012, 2013, and 2014), while the wheat straw biomass and the total aboveground biomass were measured 6 times (in 2007, 2008, 2009, 2011, 2012, and 2014) in both the control and the agroforestry plot (Dufour et al., 2013) using sampling subplots of $1 \mathrm{~m}^{2}$ each. In the control plot, five subplots have been sampled, while in the agroforestry plot five transects have been sampled. Each transect was made up of three subplots, $2 \mathrm{~m}$ north from the tree, $2 \mathrm{~m}$ south from the tree, and $6.5 \mathrm{~m}$ from the tree (middle of the alley). In March 2012, a $2 \mathrm{~m}$ deep pit was opened in the agricultural control plot (Prieto et al., 2015), and the root biomass was quantified to the maximum rooting depth $(1.5 \mathrm{~m})$. The root: shoot ratio of durum wheat was measured in the control plot. We assumed that the crop root biomass turns out once a year after the crop harvest.

\subsubsection{Aboveground and belowground input from the tree row herbaceous vegetation}

As two types of herbaceous vegetation grow in the tree rows during the year, samples were taken in summer and winter. In late June 2014, 12 subplots of $1 \mathrm{~m}^{2}$ each were positioned in the tree rows around four walnut trees. In January 2015, six subplots of $1 \mathrm{~m}^{2}$ each were positioned in the tree rows around two walnut trees. The middle of each subplot was located at 1,2, and $3 \mathrm{~m}$, respectively, from the selected walnut tree. All the aboveground vegetation was collected in each square. In the middle of each subplot, root biomass was sampled with a cylindrical soil corer (inner diameter of $8 \mathrm{~cm}$ ). Soil was taken at three soil layers, $0.0-0.1,0.1-0.3$, and $0.3-$ $0.5 \mathrm{~m}$. In the laboratory, soil was gently washed with water through a $2 \mathrm{~mm}$ mesh sieve, and roots were collected. Roots from the herbaceous vegetation were easily separated manually from walnut roots, as they were soft and yellow compared to walnuts roots that were black. After being sorted out from the soil and cleaned, the root biomass was dried at $40^{\circ} \mathrm{C}$ and measured.

\subsection{Carbon concentration measurements}

All organic carbon measurements were performed with a CHN elemental analyzer (Carlo Erba NA-2000, Milan, Italy) after samples were oven-dried at $40^{\circ} \mathrm{C}$ for $48 \mathrm{~h}$ (Table 2). Dry biomasses (tDMha ${ }^{-1}$ ) of each organic matter input were multiplied by their respective organic carbon concentrations $\left(\mathrm{mg} \mathrm{Cg}^{-1}\right)$ to calculate organic carbon stocks $\left(\mathrm{tCha}^{-1}\right)$.

\subsection{General description of the CARBOSAF model}

\subsubsection{Organic carbon decomposition}

We adapted a model developed by Guenet et al. (2013) in which total SOC is split in two pools, the FOC and the humified soil organic carbon (HSOC) for each soil layer (Fig. 1a). Input to the FOC pool comes from the plant litter and the distribution of this input within the profile is assumed to depend upon depth from the surface $(z)$, distance from the tree $(d)$, and time $(t)$. Equations describing inputs to the FOC pool $\left(I_{t, z, d}\right)$ at a given time, depth, and distance are fully explained in Sect. 3.

The FOC mineralization is assumed to be governed by first-order kinetics, being proportional to the FOC pool, as given by

$$
\begin{aligned}
\text { dec_FOC }{ }_{t, z, d}= & -k_{\mathrm{FOC}} \times \mathrm{FOC}_{t, z, d} \times f_{\text {clay }, z} \times f_{\text {moist }, z} \\
& \times f_{\text {temp }, z},
\end{aligned}
$$

where $\mathrm{FOC}_{t, z, d}$ is the FOC carbon pool $\left(\mathrm{kgC} \mathrm{m}^{-2}\right)$ at a given time ( $t$, in years), depth $(z$, in $\mathrm{m})$, and distance $(d$, in $\mathrm{m})$, and $k_{\mathrm{FOC}}$ is its decomposition rate. The potential decomposition rates of the different plant materials were assessed with a 16week incubation experiment during a companion study at the site (Prieto et al., 2016). The decomposition rate $k_{\mathrm{FOC}}$ was weighted by the respective contribution of each type of plant litter as a function of the tree age, soil depth, and distance from the tree. The rate modifiers $f_{\text {clay }, z}, f_{\text {moist }, z}$, and $f_{\text {temp }, z}$ are functions depending respectively on the clay content, soil moisture, and soil temperature at a given depth $z$ and range between 0 and 1 .

The $f_{\text {clay }}$ function originated from the CENTURY model (Parton et al., 1987):

$f_{\text {clay }, z}=1-0.75 \times \mathrm{Clay}_{z}$,

where $\mathrm{Clay}_{z}$ is the clay fraction (ranging between 0 and 1 ) of the soil at a given depth $z$.

The $f_{\text {moist, } z}$ function originated from the meta-analysis of Moyano et al. (2012) and is affected by soil properties (clay content, SOC content). Briefly, the authors fitted linear models on 310 soil incubations to describe the effect of soil moisture on decomposition. Then, they normalized such linear models between 0 and 1 to apply these functions to classical first-order kinetics. All details are described in Moyano et al. (2012). To save computing time, we calculated $f_{\text {moist, } z}$ only once using measured SOC stocks instead of using modeled SOC stocks and repeated the calculation at each time step.

The temperature sensitivity of the soil respiration is expressed as $Q_{10}$ :

$f_{\text {temp, } z}=Q_{10}^{\frac{\text { temp }_{z}-\text { temp }_{\text {opt }}}{10}}$,

with temp $z$ being the soil temperature in $\mathrm{K}$ at each soil depth $z$ and temp $\mathrm{p}_{\text {opt }}$ a parameter fixed to $304.15 \mathrm{~K}$. The $Q_{10}$ value 
Table 2. Organic carbon concentrations and $\mathrm{C}: \mathrm{N}$ ratio of the different types of biomass.

\begin{tabular}{lrrr}
\hline Type of biomass & $\begin{array}{r}\text { Organic C concentration } \\
\left(\mathrm{mg} \mathrm{Cg}^{-1}\right)\end{array}$ & $\mathrm{C}: \mathrm{N}$ & $\begin{array}{r}\text { Number of } \\
\text { replicates }\end{array}$ \\
\hline Walnut trunk & $445.7 \pm 1.0$ & $159.1 \pm 25.2$ & 3 \\
Walnut branches & $428.6 \pm 1.7$ & $62.2 \pm 11.7$ & 3 \\
Wheat straw & $433.2 \pm 0.7$ & $55.5 \pm 2.1$ & 5 \\
Wheat root & $351.4 \pm 19$ & $24.8 \pm 2.1$ & 8 \\
Walnut leaf & $449.4 \pm 3.7$ & $49.1 \pm 0.4$ & 3 \\
Walnut fine root & $437.0 \pm 3.3$ & $28.6 \pm 3.4$ & 8 \\
Summer vegetation (ABG) & $448.4 \pm 1.9$ & $37.8 \pm 2.2$ & 5 \\
Summer vegetation (roots) & $314.5 \pm 8.3$ & $33.8 \pm 1.7$ & 6 \\
Winter vegetation (ABG) & $447.7 \pm 5.3$ & $11.2 \pm 0.4$ & 3 \\
Winter vegetation (roots) & $397.4 \pm 5.0$ & $24.7 \pm 0.7$ & 3 \\
\hline
\end{tabular}

The organic matter called "vegetation" stands for the herbaceous vegetation that grows in the tree row. ABG: aboveground. Errors represent standard errors.

was fixed to 2, a classical value used in models (Davidson and Janssens, 2006).

Once the FOC is decomposed, a fraction is humified $(h)$ and another is respired as $\mathrm{CO}_{2}(1-h)$ (Fig. 2a) following Eqs. (4) and (5).

Humified $\mathrm{FOC}_{t, z, d}=h \times$ dec_FOC $t, z, d$

Respired $\mathrm{FOC}_{t, z, d}=(1-h) \times$ dec_FOC $t, z, d$

Two mathematical approaches are available in the model to describe the mineralization of HSOC: a first-order kinetics, as given by Eq. (6), or an approach developed by Wutzler and Reichstein (2008) and by Guenet et al. (2013) introducing the priming effect, i.e., the mineralization of HSOC depends on FOC availability, and given by Eq. (7):

$$
\begin{aligned}
\text { dec_HSOC }_{t, z, d}= & -k_{\mathrm{HSOC}, z} \times \mathrm{HSOC}_{t, z, d} \times f_{\text {moist }, z} \\
& \times f_{\text {temp, } z} \\
\text { dec_HSOC }_{t, z, d}= & -k_{\mathrm{HSOC}, z} \times \mathrm{HSOC}_{t, z, d} \\
& \times\left(1-e^{-\mathrm{PE} \mathrm{FOC}_{t, z, d}}\right) \times f_{\text {moist }, z} \times f_{\text {temp }, z},
\end{aligned}
$$

where $\mathrm{HSOC}_{t, z, d}$ is the humified SOC carbon pool at a given time ( $t$, in years), depth $(z$, in $\mathrm{m})$, and distance $(d$, in $\mathrm{m})$, $k_{\mathrm{HSOC}, z}$ is its decomposition rate $\left(\mathrm{yr}^{-1}\right)$ at a given depth $z$, and PE is the priming effect parameter. The parameters $f_{\text {moist, } z}$ and $f_{\text {temp, } z}$ are functions depending respectively on soil moisture and soil temperature at a given depth $z$ and affecting the decomposition rate of HSOC. They correspond to the moisture equation from Moyano et al. (2012) and to Eq. (3), respectively. The decomposition rate $k_{\mathrm{HSOC}, z}$ is an exponential law depending on soil depth $(z)$ as shown by an incubation study (see paragraph on HSOC decomposition rate in Sect. 2):

$k_{\mathrm{HSOC}, z}=a \times e^{-b \times z}$.

The $b$ parameter of this equation represented the ratio of labile $\mathrm{C}$ /stable $\mathrm{C}$ within the HSOC pool. The effect of clay on
HSOC decomposition was implicitly taken into account in this equation as clay content increased with soil depth.

A fraction of decomposed HSOC returns to the FOC assuming that part of the HSOC decomposition products is as labile as FOC $(h)$ and another is respired as $\mathrm{CO}_{2}$ (Fig. 2a) in the two-pool model.

Finally, we also developed an alternative version of the model with three pools by splitting the HSOC pools into two pools with different turnover rates, HSOC2 being more stabilized than HSOC1 (Fig. 2b). The non-respired decomposed FOC is split between HSOC1 and HSOC2 following a parameter $f_{1}$. The non-respired decomposed HSOC1 is split between HSOC2 and FOC following a parameter $f_{2}$, whereas non-respired decomposed HSOC2 is only redistributed into the FOC pools. The decomposition of HSOC1 and HSOC2 both follow Eq. (8) but with different parameter values for $a$.

\subsubsection{Carbon transport mechanisms}

The transport of $\mathrm{C}$ between the different soil layers was represented by both advection and diffusion mechanisms (Elzein and Balesdent, 1995), which have been shown to describe the C transport in soils well (Bruun et al., 2007; Guenet et al., 2013). The advection represents the $\mathrm{C}$ transport due to water infiltration in the soil, while the diffusion represents the $\mathrm{C}$ transport due to fauna activity. The same transport coefficients were applied to the two C pools, FOC and HSOC.

The advection is defined by

$F_{\mathrm{A}}=A \times \mathrm{C}$,

where $F_{\mathrm{A}}$ is the flux of $\mathrm{C}$ transported downwards by advection, and $A$ is the advection rate $\left(\mathrm{mm} \mathrm{yr}^{-1}\right)$.

The diffusion is represented by Fick's law:

$$
F_{\mathrm{D}}=-D \times \frac{\partial^{2} \mathrm{C}}{\partial z^{2}}
$$


where $F_{\mathrm{D}}$ is the flux of $\mathrm{C}$ transported downwards by diffusion, $-D$ the diffusion coefficient $\left(\mathrm{cm}^{2} \mathrm{yr}^{-1}\right)$, and $\mathrm{C}$ the amount of carbon in the pool subject to transport (FOC or HSOC).

To represent the effect of soil tillage $(z \leq 0.2 \mathrm{~m})$, we added another diffusion term using Fick's law but with a value of $D$ several orders of magnitude higher to represent mixing due to tillage. It must be noted that no tillage effect on the decomposition was represented here because of the large unknowns in these aspects (Dimassi et al., 2013; Virto et al., 2012).

In this model, the flux of $\mathrm{C}$ transported downwards by the advection and diffusion $\left(F_{\mathrm{AD}}\right)$ was represented as the sum of both mechanisms, following Elzein and Balesdent (1995):

$F_{\mathrm{AD}}=F_{\mathrm{A}}+F_{\mathrm{D}}$

The FOC and HSOC pool dynamics in the two-pool model correspond to

$$
\begin{aligned}
& \frac{\partial \mathrm{FOC}_{t, z, d}}{\partial t}=I_{t, z, d}+\frac{\partial F_{\mathrm{AD}}}{\partial z}+h \times \text { dec_HSOC } t, z, d \\
& - \text { dec_FOC }{ }_{t, z, d} \text {, } \\
& \frac{\partial \mathrm{HSOC}_{t, z, d}}{\partial t}=\frac{\partial F_{\mathrm{AD}}}{\partial z}+h \times \text { dec_FOC }_{t, z, d} \\
& - \text { dec_HSOC } t, z, d \text {. }
\end{aligned}
$$

Finally, the FOC, HSOC1, and HSOC2 pool dynamics in the three-pool model correspond to

$$
\begin{aligned}
& \frac{\partial \mathrm{FOC}_{t, z, d}}{\partial t}=I_{t, z, d}+\frac{\partial F_{\mathrm{AD}}}{\partial z}+h \times f_{2} \times \text { dec_HSOC1 } 1_{t, z, d} \\
& +h \times \text { dec_HSOC } 2_{t, z, d}-\text { dec_FOC }{ }_{t, z, d}, \\
& \frac{\partial \mathrm{HSOC} 1}{\partial t \partial}=\frac{\partial F_{\mathrm{AD}}}{\partial z}+h \times f_{1} \times \text { dec_FOC } \mathrm{FOC}_{t, z, d} \\
& - \text { dec_HSOC1 } 1_{t, z, d} \text {, } \\
& \frac{\partial \mathrm{HSOC} 2}{\partial t}=\frac{\partial F_{\mathrm{AD}}}{\partial z}+h \times\left(1-f_{1}\right) \times \text { dec_FOC } t, z, d \\
& +h \times\left(1-f_{2}\right) \times \text { dec_HSOC1 } 1_{t, z, d} \\
& - \text { dec_HSOC } 2_{t, z, d} \text {. }
\end{aligned}
$$

\subsubsection{Depth dependence of HSOC potential decomposition rates}

The shape of the function (i.e., the $b$ parameter) describing the HSOC potential decomposition rate (Eq. 8) was determined by incubating soils from the control, the alley, and the tree row and from different soil layers $(0.0-0.1,0.1-0.3,0.7-$ 1.0 , and $1.6-1.8 \mathrm{~m})$. Soils were sieved at $5 \mathrm{~mm}$ and incubated during 44 days at $20^{\circ} \mathrm{C}$ at a water potential of $-0.03 \mathrm{MPa}$. Evolved $\mathrm{CO}_{2}$ was measured using a micro $\mathrm{GC}$ at $1,3,7$, 14, 21, 28, 35, and 44 days. The first three measurement dates corresponded to a pre-incubation period and were not included in the analysis. For a given depth, the cumulative mineralized SOC was expressed as a percentage of total SOC and was plotted against the incubation time. The slopes represented the potential SOC mineralization rate at a given soil depth and location. The potential SOC mineralization rates were then plotted against soil depth (Fig. S1 in the Supplement). We used the soil incubations to determine only the $b$ parameter of the curve: with such short-term incubations, the SOC decomposition rate over the soil profile is overestimated because the $\mathrm{CO}_{2}$ measured during the incubations mainly originates from the labile $\mathrm{C}$ pool. The $a$ parameter was optimized following the procedure described further.

\subsection{Boundary conditions of the CARBOSAF model}

\subsubsection{Annual aggregates of soil temperature and soil moisture}

In April 2013, eight soil temperature and moisture sensors (Campbell CS 616 and Campbell 107, respectively) were installed in the agroforestry plot at $0.3,1.3,2.8$, and $4.0 \mathrm{~m}$ of depth and at 2 and $5 \mathrm{~m}$ from the trees. Soil temperature and moisture were measured for 11 months.

The mean annual soil temperature in the agroforestry plot was described by the following equation:

$T=-0.89 \times z+288.24 \quad\left(R^{2}=0.99\right)$,

where $T$ is the soil temperature $(\mathrm{K})$ and $z$ is the soil depth (m).

The mean annual soil moisture was described with the following equation:

$\theta=0.05 \times z+0.28 \quad\left(R^{2}=0.99\right)$,

where $\theta$ is the soil volumetric moisture $\left(\mathrm{cm} \mathrm{cm}^{-3}\right)$ and $z$ is the soil depth (m).

Due to a lack of data in the agricultural plot, we assumed that the soil temperature and the soil moisture were the same in the agroforestry tree rows, alleys, and in the control plot, but we further performed a sensitivity analysis of the model on these two parameters.

\subsubsection{Interpolation of tree growth}

The tree growth has been measured in the field since the establishment of the experiment. We used the diameter at breast height (DBH) as a surrogate for the tree growth preferentially to the tree height as the field measurements were more accurate. Indeed, DBH is easier to measure than height, especially when trees are older. To describe the temporal dynamic of DBH since the tree planting, a linear equation was fitted on the data.

Tree growth measurements enabled us to fit the following equation that was used in the model:

$\mathrm{DBH}_{t}\left\{\begin{array}{lll}0.01, & t \leq 3 \\ 0.0157 \times t-0.0391 & \left(R^{2}=0.997\right) & 3<t \leq 20,\end{array}\right.$

where $\mathrm{DBH}_{t}$ is the diameter at breast height $(\mathrm{m})$ and $t$ represents the time since tree planting (years). 


\subsubsection{Change in tree litterfall over time}

For the five walnut trees for which the leaf biomass was quantified, DBH was also measured. The ratio between the leaf biomass and DBH was then calculated for the five replicates. Total leaf biomass was $8.96 \pm 1.45 \mathrm{~kg} \mathrm{DM}$ tree $^{-1}$ and the carbon concentration of walnut leaves was $449.4 \pm 3.7 \mathrm{mg} \mathrm{Cg}^{-1}$ (Table 2). With a density of 110 treesha $^{-1}$, leaf litterfall was estimated at $0.73 \pm 0.06 \mathrm{tCha}^{-1}$ in 2012 and on the plot scale. The ratio between leaf biomass and DBH was $0.0277 \pm 0.0024 \mathrm{tC}_{\text {tree }}^{-1} \mathrm{~m}^{-1}$ or $3.05 \mathrm{tCha}^{-1} \mathrm{~m}^{-1}$. The following linear relationship was therefore used in the model to describe leaf litter $\mathrm{C}$ input with the tree growth:

$L_{t}=3.05 \times \mathrm{DBH}_{t}$,

where $L_{t}$ is the leaf litter input $\left(\mathrm{tCha}^{-1}\right)$ at year $t$, and $\mathrm{DBH}_{t}$ the diameter at breast height $(\mathrm{m})$ at year $t$.

\subsubsection{Tree fine root $\mathrm{C}$ input from mortality}

In 2012, the measured tree fine root biomass was higher in the tree row than in the alley (Table S1). From 0 to $1 \mathrm{~m}$ of distance from the tree (in the tree row), the tree fine root biomass was homogeneous and was $1.01 \mathrm{tCha}^{-1}$ down to $2 \mathrm{~m}$ of depth.

In 2012 and in the alley, the tree fine root biomass (TFRB) decreased with increasing distance from the tree and was represented by an exponential function:

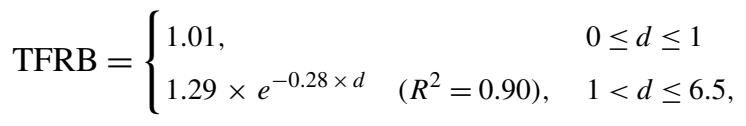

where TFRB represents tree fine root biomass down to $2 \mathrm{~m}$ of depth $\left(\mathrm{tCha}^{-1}\right)$ and $d$ the distance from the tree (m).

We considered a linear increase in TFRB with increasing $\mathrm{DBH}$, and a linear regression was performed between TFRB in 2012 and TFRB in 1996, the first year after planting (biomass considered as negligible). The following linear relationship was used to simulate TFRB as a function of tree growth:

$\mathrm{TFRB}_{t, d}= \begin{cases}3.69 \times \mathrm{DBH}_{t}, & 0 \leq d \leq 1 \\ 4.70 \times \mathrm{DBH}_{t} \times e^{-0.28 \times d}, & 1<d \leq 6.5,\end{cases}$

where $\mathrm{TFRB}_{t}$ represents the tree fine root biomass to $2 \mathrm{~m}$ of depth $\left(\mathrm{tCha}^{-1}\right)$ at year $t, \mathrm{DBH}_{t}$ the diameter at breast height (m) at year $t$, and $d$ the distance to the tree (m).

A changing distribution of tree fine roots within the soil profile was taken into account with increasing distance to the tree. For this purpose, exponential functions $\left(a \times e^{-b \times z}\right)$ were fitted in the alley every $0.5 \mathrm{~m}$ of distance, and a linear regression was fitted between their coefficients $a$ and $b$ and distance from the tree. However, the distribution of TFRB within the soil profile and with the distance to the tree was considered constant with time.
A decreasing exponential function best represented the changing distribution of tree fine roots within the soil profile with increasing distance to the tree:

$$
\begin{aligned}
& p_{\mathrm{TFRB}, z, d}= \\
& \left\{\begin{array}{lll}
13.92 \times e^{-1.39 \times z} & \left(R^{2}=0.68\right), & 0 \leq d \leq 1 \\
a \times e^{-b \times z}, & 1<d \leq 6.5,
\end{array}\right.
\end{aligned}
$$

and

$$
\begin{array}{ll}
a=10.31-1.15 \times d & \left(R^{2}=0.69\right) \\
b=-1.10+0.19 \times d \quad & \left(R^{2}=0.51\right) .
\end{array}
$$

Finally,

$$
\begin{aligned}
& p_{\text {TFRB }, z, d}= \\
& \begin{cases}13.92 \times e^{-1.39 \times z}, & 0 \leq d \leq 1 \\
(10.31-1.15 \times d) \times e^{-(-1.10+0.19 \times d) \times z}, & 1<d \leq 6.5,\end{cases}
\end{aligned}
$$

where $p_{\mathrm{TFRB}, z, d}$ is the proportion (\%) of the total tree fine root biomass (TFRB) at a given depth $z(\mathrm{~m})$ and at a distance $d$ from the tree $(\mathrm{m})$.

To finally estimate the tree fine root input due to mortality, TFRB was multiplied by the measured root turnover. The tree fine root turnover ranged from 1.7 to $2.8 \mathrm{yr}^{-1}$ depending on fine root diameter, with an average turnover of $2.2 \mathrm{yr}^{-1}$ for fine roots $\leq 2 \mathrm{~mm}$ and to a depth of $2 \mathrm{~m}$ (Germon et al., 2016).

\subsubsection{Aboveground and belowground input from the crop}

As there were more crop yield measurements (Eq. 14) than straw biomass measurements (Eq. 6), the effect of agroforestry on the crop yield with time was used as an estimate for change in the aboveground and belowground wheat biomass.

For this, the relative yield $\left(\operatorname{Rel} Y_{\mathrm{AF}}\right)$ in the agroforestry system was calculated for each year as the ratio between the agroforestry yield and the control yield $\left(Y_{\mathrm{C}}\right)$.

The average annual crop yield in the control plot was $Y_{\mathrm{C}}=3.79 \pm 0.40 \mathrm{tDMha}^{-1}$ for the 14 studied years. In the agroforestry plot, the average relative yield decreased linearly with time (increasing DBH) and was described using the following linear equation (Fig. 3):

$\operatorname{Rel} Y_{\mathrm{AF}_{t}}=-93.33 \times \mathrm{DBH}_{t}+100$

$\left(R^{2}=0.12, \quad p\right.$ value $\left.=0.02\right)$,

where $\operatorname{Rel} Y_{\mathrm{AF}_{t}}$ is the average relative crop yield (\%) in the agroforestry plot compared to the control plot at year $t$, and $\mathrm{DBH}_{t}$ is the diameter at breast height (m) at year $t$.

The variation in crop yield with distance from the trees was described with a quadratic equation (Fig. 2). But as we 
aimed to predict SOC stocks up to $6.5 \mathrm{~m}$ of distance from the trees (middle of the alley), a linear increase in crop yield with increasing distance from the tree gave similar results as the quadratic equation over the $6.5 \mathrm{~m}$ distance and was more parsimonious:

$\operatorname{Rel} Y_{\mathrm{AF}_{\mathrm{d}}}=4.39 \times d+64.57 \quad\left(R^{2}=0.24\right), \quad 1<d \leq 6.5$,

where $\operatorname{Rel} Y_{\mathrm{AF}_{\mathrm{d}}}$ is the relative crop yield (\%) in the agroforestry plot at a distance $d(\mathrm{~m})$ from the tree compared to the control plot.

Finally, the crop yield in the agroforestry plot was modeled as follows:

$Y_{\mathrm{AF}_{t, d}}=\operatorname{Rel} Y_{\mathrm{AF}_{t}} \times Y_{\mathrm{C}} \times \operatorname{Rel} Y_{\mathrm{AF}_{\mathrm{d}}}$

$\left(R^{2}=0.19\right), \quad 1<d \leq 6.5$,

where $Y_{\mathrm{AF}_{t, d}}$ is the crop yield ( $\mathrm{tDMha}^{-1}$ ) in the agroforestry plot at year $t$ and at a distance $d(\mathrm{~m})$ from the tree. Because three linear equations were used to describe the crop yield in the agroforestry plot, errors were accumulated and we finally came up with a standard underestimation of the crop yield in the agroforestry plot that we corrected by multiplying our equation by 1.2 .

The ratio between the straw biomass and the crop yield was calculated as the average of the six measurements and was considered constant with time. This ratio was used to convert crop yield into straw biomass. In the agroforestry plot, the carbon input to the soil from the aboveground crop biomass was

$\mathrm{ABC}_{\text {crop }, t, d}=Y_{\mathrm{AF}_{t, d}} \times($ straw biomass : crop yield $)$

$$
\times C_{\text {straw }} \times(1-\text { export }) \text {, }
$$

where $\mathrm{ABC}_{\mathrm{crop}, t, d}$ is the aboveground carbon input from the crop $\left(\mathrm{tCha}^{-1}\right)$ at year $t$ and distance $d$ from the tree, and $Y_{\mathrm{AF}_{t, d}}$ is the agroforestry crop yield. The average ratio between the straw biomass $\left(\mathrm{tDMha}^{-1}\right)$ and the crop yield $\left(\mathrm{tDMha}^{-1}\right)$ equaled $1.03 \pm 0.11(n=6)$. The wheat straw was exported out of the field after the harvest, but it was estimated that $25 \%$ of the straw biomass was left on the soil, and thus export was 0.75 . In the control plot, $Y_{\mathrm{AF}_{t, d}}$ was replaced by $Y_{\mathrm{C}}$.

To estimate the fine root biomass of the crop, we hypothesized that the root: shoot ratio of the durum wheat was the same in both the agroforestry and agricultural plot in the absence of any published data on the matter. In the agroforestry plot, the belowground crop biomass was represented by

$$
\begin{aligned}
\mathrm{BEC}_{\mathrm{crop}, t, d}= & Y_{\mathrm{AF}_{t, d}} \times(\text { shoot }: \text { crop yield }) \times(\text { root : shoot }) \\
& \times C_{\text {root }},
\end{aligned}
$$

where $\mathrm{BEC}_{\mathrm{crop}, t, d}$ is the belowground crop biomass $\left(\mathrm{tCha}^{-1}\right)$ at year $t$ and at a distance $d$ from the tree, and $Y_{\mathrm{AF}_{t, d}}$ is the agroforestry crop yield. The average ratio between the total crop aboveground biomass (shoot) and the
Table 3. Wheat fine root biomass in the agricultural control plot in 2012.

\begin{tabular}{lrr}
\hline & \multicolumn{2}{c}{ Wheat fine root biomass } \\
\cline { 2 - 3 } Soil depth $(\mathrm{m})$ & $\left(\mathrm{kgC}^{-3}\right)$ & $\left(\mathrm{tCha}^{-1}\right)$ \\
\hline $0.0-0.1$ & $0.48 \pm 0.05$ & $0.48 \pm 0.05$ \\
$0.1-0.3$ & $0.34 \pm 0.04$ & $0.69 \pm 0.09$ \\
$0.3-0.5$ & $0.22 \pm 0.04$ & $0.44 \pm 0.08$ \\
$0.5-1.0$ & $0.10 \pm 0.04$ & $0.52 \pm 0.20$ \\
$1.0-1.5$ & $0.03 \pm 0.04$ & $0.17 \pm 0.19$ \\
\hline Total & - & $2.29 \pm 0.32$ \\
\hline
\end{tabular}

Errors represent standard errors.

Table 4. Aboveground and belowground biomass of the herbaceous vegetation in the tree rows.

\begin{tabular}{lrcr}
\hline & & \multicolumn{2}{c}{ Herbaceous biomass $\left(\mathrm{tCha}^{-1}\right)$} \\
\cline { 3 - 4 } & $\begin{array}{r}\text { Soil } \\
\text { depth }(\mathrm{m})\end{array}$ & Summer & Winter \\
\hline Aboveground & - & $1.57 \pm 0.11$ & $0.56 \pm 0.09$ \\
Belowground & $0.0-0.1$ & $0.22 \pm 0.03$ & $0.17 \pm 0.01$ \\
& $0.1-0.3$ & $0.16 \pm 0.02$ & $0.06 \pm 0.01$ \\
& $0.3-0.5$ & $0.09 \pm 0.04$ & $0.04 \pm 0.01$ \\
\hline & Total & $0.46 \pm 0.04$ & $0.27 \pm 0.02$
\end{tabular}

Errors represent standard errors.

crop yield equaled $2.45 \pm 0.15(n=6)$. In 2012, total fine root biomass was $2.29 \pm 0.32 \mathrm{tCha}^{-1}$ in the control (Table 3 ).

Therefore, the wheat root : shoot ratio equaled $0.79 \pm 0.12$ $(n=1)$. The carbon concentration of wheat root was $C_{\text {root }}=$ $35.14 \pm 1.90 \mathrm{mg} \mathrm{Cg}^{-1}$. In the control plot, $Y_{\mathrm{AF}_{t, d}}$ was replaced by $Y_{\mathrm{C}}$.

In 2012, no wheat roots were observed below $1.5 \mathrm{~m}$, and root biomass decreased exponentially with increasing depth (Table 3). The distribution of crop roots within the soil profile was described as follows:

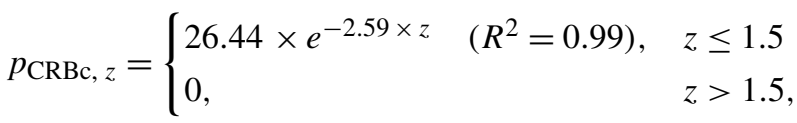

where $p_{\mathrm{CRBc}, z}$ is the proportion (\%) of total crop root biomass in the control plot at a given depth $z(\mathrm{~m})$.

Since the same maximum rooting depth of the crop was observed in the agroforestry plot and in the control plot, we inferred that the wheat root distribution within the soil profile was not modified by agroforestry, but only its biomass. The crop root turnover was assumed to be $1 \mathrm{yr}^{-1}$, with root mortality occurring mainly after crop harvest. 


\subsubsection{Aboveground and belowground input from herbaceous vegetation in the tree rows}

The distance from the trees had no effect on the aboveground and belowground biomass of the herbaceous vegetation (data not shown), and therefore average values are presented. The summer aboveground biomass was almost 3 times higher than in winter, whereas the belowground biomass was 2 times higher (Table 4). The total aboveground carbon input was $2.13 \pm 0.14 \mathrm{tCha}^{-1} \mathrm{yr}^{-1}$ and the total belowground carbon input was $0.74 \pm 0.05 \mathrm{tCha}^{-1} \mathrm{yr}^{-1}$ to $0.5 \mathrm{~m}$ of depth.

The belowground carbon input from the tree row vegetation $\left(\mathrm{BEC}_{\mathrm{veg}, z}, \mathrm{tC} \mathrm{ha}^{-1}\right)$ at a given depth $z(\mathrm{~m})$ was described by the following equation:

$\mathrm{BEC}_{\mathrm{veg}, z}= \begin{cases}0.44 \times e^{-3.12 \times z} & z \leq 1.5 \\ 0, & z>1.5 .\end{cases}$

We assumed for simplification that the aboveground and belowground biomasses of the herbaceous vegetation in the tree row were constant over time.

\subsection{Optimization procedure}

Depending on the model variant, four to five parameters were optimized with a gradient-based statistical method (Santaren et al., 2007; Tarantola, 1987, 2005) using measured SOC stocks from the control plot only. These parameters were $A$ the advection rate, $D$ the diffusion coefficient, $h$ the humification yield, $a$ the coefficient of the $k_{\mathrm{HSOC}}$ rate from Eq. (10), and PE the priming coefficient. These four to five parameters were calibrated so that equilibrium SOC stocks, i.e., after 5000 years of simulation, equaled SOC stocks of the control plot in 2013. The associated uncertainty was estimated with the 93 soil cores sampled in the control plot (see Sect. 2.2.1). Due to a lack of relevant data, we assumed that the climate and the land use were the same for the last 5000 years and that SOC stocks in the control plot were at equilibrium at the time of measurement. Therefore, SOC stocks at the end of the 5000 years of simulation equaled SOC stocks in the control plot. Three different calibrations were performed corresponding to the three model variants that were used: one calibration with the two-pool model without the priming effect, one calibration with the two-pool model with the priming effect, and one calibration with the three-pool model.

Each model variant was fitted to the control SOC stock data using a curve-fitting method described in Tarantola (1987), after a conversion from SOC stocks in $\mathrm{kg} \mathrm{Cm}^{-2}$ to SOC stocks in $\mathrm{kg} \mathrm{m}^{-3}$ due to the different soil layer thicknesses. We aimed to find a parameter set that minimizes the distance between model outputs and the corresponding observations considering model and data uncertainties and starting parameter information. With the assumption of Gaussian errors for both the observations and the starting pa- rameters, the optimal parameter set corresponds to the minimum of the cost function $\mathbf{J}(\mathbf{x})$ :

$$
\begin{aligned}
\mathbf{J}(\mathbf{x})= & 0.5 \times\left[(\mathbf{y}-\mathbf{H}(\mathbf{x}))^{t} \times \mathbf{R}^{-1} \times(\mathbf{y}-\mathbf{H}(\mathbf{x}))+\left(\mathbf{x}-\mathbf{x}_{b}\right)^{t}\right. \\
& \left.\times \mathbf{P}_{b}^{-1} \times\left(\mathbf{x}-\mathbf{x}_{b}\right)\right]
\end{aligned}
$$

which contains both the mismatch between modeled and observed SOC stock and the mismatch between starting and optimized parameters; $\mathbf{x}$ is the vector of unknown parameters, $\mathbf{x}_{b}$ the vector of starting parameter values fixed for each optimization procedure, $\mathbf{H}()$ the model, and $\mathbf{y}$ the vector of observations. The covariance matrices $\mathbf{P}_{b}$ and $\mathbf{R}$ describe a priori uncertainties in parameters and observations, respectively. Both matrices are diagonal as we suppose the observation uncertainties and the parameter uncertainties to be independent. The covariance matrices $\mathbf{P}_{b}$ are presented in Table S2. To determine an optimal set of parameters that minimizes $\mathbf{J}(\mathbf{x})$, we used the BFGS gradient-based algorithm (Tarantola, 1987). For each model variant, we performed 30 optimizations with different starting parameter values to check that the results did not correspond to a local minimum. As the BFGS algorithm does not directly calculate the variance of posteriors, they were quantified using the curvature cost function at its minimum once it was reached (Santaren et al., 2007).

\subsection{Comparison of models}

Model predictions with and without the priming effect were compared by calculating the coefficients of determination, root mean square error (RMSE), and Bayesian information criteria (BIC).

RMSE $=\sqrt{\frac{1}{N} \sum_{i=1}^{N}\left(x_{i}-\bar{x}\right)^{2}}$,

where $i$ is the number of observations ( 1 to $N), x_{i}$ is the predicted value, and $\bar{x}$ is the mean observed value.

$\mathrm{BIC}=k \times \ln (N)-2 \times \ln (\hat{L})$,

where $N$ is the number of observations, $k$ is the number of model parameters, and $\hat{L}$ is the maximized value of the likelihood function of the model (Schwarz, 1978).

The model was run at a yearly time step using mean annual soil temperature and moisture and annual $\mathrm{C}$ inputs to the soil. In the agroforestry plot, the model was run from the ground $(0 \mathrm{~m})$ to $2 \mathrm{~m}$ of depth and from the tree $(0 \mathrm{~m})$ to $6.5 \mathrm{~m}$ from the tree (middle of the alley). The model was applied separately across locations of a tree-distance gradient having varying OC inputs, and each soil column was considered independent from another. SOC pools were initialized after a spin-up of 5000 years in the control plot. At $t_{0}$, SOC stocks in the agroforestry plot therefore equaled SOC stocks of the control plot. The model was then run from $t_{0}$ to $t_{18}$ (years) 
after tree planting. The spatial resolution was $0.1 \mathrm{~m}$ both vertically and horizontally. The model was developed using $\mathrm{R}$ 3.1.1 (R Development Core Team, 2013). Partial differential equations were solved using the $\mathrm{R}$ package deSolve and the ode.1D method (Soetaert et al., 2010).

\section{Results}

\subsection{Organic carbon inputs and SOC stocks: a synthesis from field measurements}

In the alleys of the 18-year-old agroforestry system, measured organic carbon (OC) inputs from the crop residues and roots were reduced compared to the control plot due a lower crop yield (Fig. 4). This reduction in crop OC inputs was offset by OC inputs from the tree roots and tree litterfall. Total root OC inputs in the alleys (crop + tree roots) and in the control plot (crop roots) were very similar, respectively 2.43 and $2.29 \mathrm{tCha}^{-1} \mathrm{yr}^{-1}$. Alleys received $0.60 \mathrm{tCha}^{-1} \mathrm{yr}^{-1}$ more total aboveground biomass (crop residues + tree litterfall) than the control, which was added to the plough layer. Tree rows received $2.35 \mathrm{tCha}^{-1} \mathrm{yr}^{-1}$ more $\mathrm{C}$ inputs in the first $0.3 \mathrm{~m}$ of soil compared to the control plot, mainly from the herbaceous vegetation. Down the whole soil profile, tree rows received 2 times more OC inputs compared to the control plot (Fig. 4) and $65 \%$ more than alleys. Overall, the agroforestry plot had $41 \%$ more OC inputs to the soil than the control plot to $2 \mathrm{~m}$ of depth ( $3.80 \mathrm{tCha}^{-1} \mathrm{yr}^{-1}$ compared to $2.69 \mathrm{tCha}^{-1} \mathrm{yr}^{-1}$ ). In the agroforestry plot, the largest aboveground $\mathrm{OC}$ input to the soil comes from the herbaceous vegetation, and not from the trees. In the control plot, $85 \%$ of OC input is wheat root litter. In the agroforestry plot, root inputs represent $71 \%$ of OC inputs in the alleys and $50 \%$ in the tree rows.

In the first $0.3 \mathrm{~m}$ of soil, SOC stocks were significantly higher in the alleys than in the control plot, but the difference was small $\left(2.1 \pm 0.6 \mathrm{tCha}^{-1}\right)$. Between 0.3 and $1.0 \mathrm{~m}$, the difference in SOC stocks was smaller but still significant. However, between 1 and $2 \mathrm{~m}$ of depth, SOC stocks were significantly lower in the alleys than in the control. As a consequence, there was no significant difference in total SOC stocks between the two locations down the whole soil profile. In the tree rows, topsoil organic carbon stocks $(0.0-0.3 \mathrm{~m})$ were much higher than in the control $\left(+17.0 \pm 1.4 \mathrm{tCha}^{-1}\right)$. This positive difference of SOC stocks decreased with depth but remained significantly positive down to $1.5 \mathrm{~m}$ of depth. The opposite was observed between 1.5 and $2.0 \mathrm{~m}$ of depth. The delta value of total SOC stocks between the tree rows and the control plot was $20.1 \pm 1.6 \mathrm{tCha}^{-1}$. On the plot scale, total SOC stocks were significantly higher in the agroforestry plot compared to the control plot down to $2 \mathrm{~m}$ of depth $\left(+3.3 \pm 0.9 \mathrm{tCha}^{-1}\right)$.

\subsection{HSOC decomposition rate}

The soil incubation experiment showed that the HSOC mineralization rate decreased exponentially with depth (Fig. S1 in the Supplement) and could be described with

$k_{\mathrm{HSOC}, z}=6.114 \times e^{-1.37 \times z} \quad\left(R^{2}=0.76\right)$,

where $z$ is the soil depth (m), and the $a\left(\mathrm{yr}^{-1}\right)$ coefficient $(a=6.114)$ was further optimized (Table 5).

\subsection{Modeling results}

\subsubsection{Optimized parameters and correlation matrix}

The optimized parameters and their starting parameter modes are presented in Table 5. For the two-pool model without the priming effect, the most important correlation was observed between $h$ and $A$, which control the humification and the transport by advection. Concerning the two-pool model with the priming effect, the most important correlations were observed between $h$ and PE, which control the effect of the FOC on HSOC decomposition, and between $h$ and $A$. $A$ and PE were also positively correlated (Fig. S2 in the Supplement). For the three-pool model, $f_{1}$ and $f_{2}$ were by definition negatively correlated, but $f_{2}$ and $A$ were also correlated. Considering the method used to optimize the parameters, these important correlation factors hinder the presentation of the model output within an envelope. Therefore, we presented the model results using the optimized parameter without any envelope.

\subsubsection{Modeled SOC stocks}

As a reminder, the SOC stocks of the agroforestry plot were not part of the model calibration (that used the control plot only) but were used here for validation. Observed SOC stocks were not well represented by the two-pool model without the priming effect, with RMSE ranging from 1.00 to $1.07 \mathrm{~kg} \mathrm{Cm}^{-3}$ (Fig. 5, Table $\mathrm{S} 3$ in the Supplement). The model performed better when the priming effect was taken into account, with RMSE ranging from 0.41 to $0.95 \mathrm{~kg} \mathrm{C} \mathrm{m}^{-3}$, and the SOC profile was well described. The representation of SOC stocks was not improved by the inclusion of a third $\mathrm{C}$ pool in the model. Overall, the two-pool model with the priming effect was the best one, as shown by the BICs (Fig. 5, Table S3 in the Supplement). For all models, SOC stocks below $1 \mathrm{~m}$ of depth were better described than SOC stocks above $1 \mathrm{~m}$ (Table S3 in the Supplement). The spatial distribution of SOC stocks and additional SOC storage was also well described (Fig. 6), with very high additional SOC storage in the topsoil layer in the tree row. Most modeled SOC storage in the agroforestry plot was located in the first $0.2 \mathrm{~m}$ of depth, but SOC storage was slightly higher in the middle of the alleys than in the alleys close to the tree rows. 

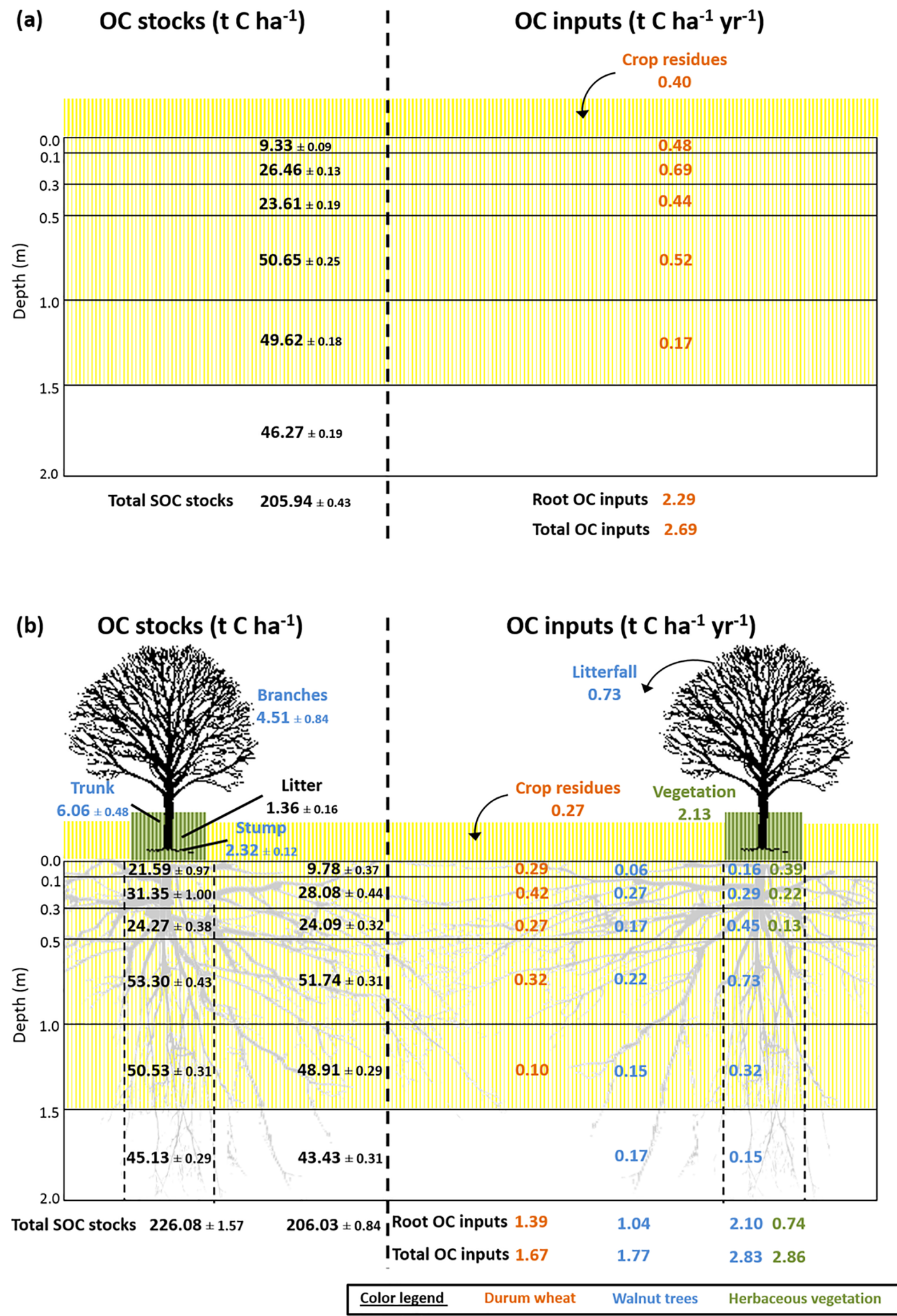

Figure 4. Measured soil organic carbon stocks and organic carbon inputs to the soil (a) in the agricultural control plot and (b) in the 18-yearold agroforestry plot. Associated errors are standard errors. Values are expressed per hectare of land type (control, alley, tree row). To get the values per hectare of agroforestry, data from the alley and tree row have to be weighted by their respective surface area (i.e., 84 and $16 \%$, respectively) and then added up. OC: organic carbon; SOC: soil organic carbon. SOC stock data are from Cardinael et al. (2015b), and data for tree root OC inputs are combined from Cardinael et al. (2015a) and Germon et al. (2016). 
Table 5. Summary of optimized model parameters.

\begin{tabular}{|c|c|c|c|c|c|}
\hline \multirow{2}{*}{$\begin{array}{l}\text { Model } \\
\text { parameter }\end{array}$} & \multirow[t]{2}{*}{ Meaning } & \multirow{2}{*}{$\begin{array}{r}\text { Starting } \\
\text { parameter } \\
\text { range }\end{array}$} & \multicolumn{3}{|c|}{ Posterior values \pm variance (starting parameter values) } \\
\hline & & & Two pools - without PE & Two pools - with PE & Three pools - without PE \\
\hline$a$ & $\begin{array}{l}\text { Coefficient from Eq. ( } 8 \text { ) of the } \\
\text { HSOC decomposition }\left(\mathrm{yr}^{-1}\right)\end{array}$ & $3.65 \mathrm{e}-6-3.65$ & $0.01 \mathrm{e}^{-2} \pm<10^{-4}\left(0.01 \mathrm{e}^{-2}\right)$ & $0.01 \mathrm{e}^{-2} \pm<10^{-4}\left(0.01 \mathrm{e}^{-2}\right)$ & 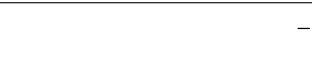 \\
\hline$a_{1}$ & $\begin{array}{l}\text { Coefficient from Eq. ( } 8 \text { ) of the } \\
\text { HSOC } 1 \text { decomposition }\left(\mathrm{yr}^{-1}\right)\end{array}$ & $3.65 e-6-3.65$ & - & - & $0.01 \mathrm{e}^{-2} \pm<10^{-4}\left(0.01 \mathrm{e}^{-2}\right)$ \\
\hline$a_{2}$ & $\begin{array}{l}\text { Coefficient from Eq. ( } 8 \text { ) of the } \\
\text { HSOC } 2 \text { decomposition }\left(\mathrm{yr}^{-1}\right)\end{array}$ & $3.65 e-6-3.65$ & - & - & $0.83 \mathrm{e}^{-2} \pm 0.17 \mathrm{e}^{-2}\left(0.83 \mathrm{e}^{-2}\right)$ \\
\hline$D$ & Diffusion coefficient $\left(\mathrm{cm}^{2} \mathrm{yr}^{-1}\right)$ & $1 \mathrm{e}-6-1$ & $4.62 \mathrm{e}^{-4} \pm 5.95 \mathrm{e}^{-4}\left(9.64 \mathrm{e}^{-4}\right)$ & $5.63 \mathrm{e}^{-4} \pm 1.42 \mathrm{e}^{-4}\left(9.01 \mathrm{e}^{-4}\right)$ & $5.24 \mathrm{e}^{-4} \pm 7.62 \mathrm{e}^{-4}\left(9.64 \mathrm{e}^{-4}\right)$ \\
\hline$A$ & Advection rate $\left(\mathrm{mm} \mathrm{yr}^{-1}\right)$ & $1 \mathrm{e}-6-1$ & $21.25 \mathrm{e}^{-4} \pm 5.02 \mathrm{e}^{-4}\left(8.54 \mathrm{e}^{-4}\right)$ & $6.63 \mathrm{e}^{-4} \pm 2.38 \mathrm{e}^{-4}\left(4.27 \mathrm{e}^{-4}\right)$ & $21.60 \mathrm{e}^{-4} \pm 2.24 \mathrm{e}^{-4}\left(8.54 \mathrm{e}^{-4}\right)$ \\
\hline$h$ & Humification yield & $0.01-1$ & $0.32 \pm<10^{-4}(0.34)$ & $0.25 \pm 1.00 \mathrm{e}^{-4}(0.13)$ & $0.34 \pm 0.03(0.34)$ \\
\hline PE & Priming coefficient & $0.1-160$ & - & $9.66 \pm 1.49(102.95)$ & - \\
\hline$f_{1}$ & $\begin{array}{l}\text { Fraction of decomposed FOC } \\
\text { entering the HSOC } 1 \text { pool }\end{array}$ & $0-1$ & - & - & $0.99 \pm 0.18(0.86)$ \\
\hline$f_{2}$ & $\begin{array}{l}\text { Fraction of decomposed HSOC1 } \\
\text { entering the FOC pool }\end{array}$ & $0-1$ & - & - & $0.94 \pm 1.10 \mathrm{e}^{-3}(0.80)$ \\
\hline
\end{tabular}

\section{Discussion}

\subsection{OC inputs drive SOC storage in agroforestry systems}

Increased SOC stocks in the agroforestry plot compared to the control may be explained by increased OC inputs, decreased OC outputs by SOC mineralization, or both. In the alleys, higher SOC stocks in the topsoil could be explained by inputs from litterfall and tree roots despite a decrease in crop inputs. Most of the additional SOC storage in the agroforestry plot was found in the topsoil in the tree rows. The same distribution was observed for OC inputs to the soil. Inputs from the herbaceous vegetation had an important impact on SOC storage. The increased SOC stocks in the tree rows were largely explained by an important aboveground carbon input $\left(2.13 \mathrm{tCha}^{-1} \mathrm{yr}^{-1}\right)$ by the herbaceous vegetation between trees. This result had already been suggested by Cardinael et al. (2015b) and Cardinael et al. (2017), who showed that even young agroforestry systems can store SOC in the tree rows while trees are still very small. These "grass strips" indirectly introduced by the tree planting in parallel tree rows have a major impact on the SOC stocks of agroforestry systems. Increased SOC stocks below the plough layer could be explained by higher root inputs, but these inputs could also have contributed to decreasing SOC stocks below $1.5 \mathrm{~m}$ due to the priming effect. On the plot scale, measured organic carbon inputs to the soil were increased by $40 \%\left(+1.1 \mathrm{tCha}^{-1} \mathrm{yr}^{-1}\right)$ down to $2 \mathrm{~m}$ of depth in the 18-year-old agroforestry plot compared to the control plot, resulting in increased SOC stocks of $3.3 \mathrm{tCha}^{-1}$. Increased OC inputs in agroforestry systems have been shown in other studies, but they were only quantified in the first $20 \mathrm{~cm}$ of soil (Oelbermann et al., 2006; Peichl et al., 2006). This study is therefore the first to also quantify deep OC inputs to soil.
In this study and due to a lack of data, soil temperature and soil moisture were considered the same in both plots so that the abiotic factors controlling SOC decomposition were identical. Reduced soil temperature is often observed in agroforestry systems (Clinch et al., 2009; Dubbert et al., 2014), but the effect of agroforestry on soil moisture is much more complex. Soil evaporation is reduced under the trees, but soil water is also lost through the transpiration of trees (Ilstedt et al., 2016; Ong and Leakey, 1999). These opposing effects vary with distance from the tree (Odhiambo et al., 2001). Moreover, increased water infiltration and water storage has been observed under the trees after a rainy event (Anderson et al., 2009). Therefore, the effect of agroforestry on soil moisture is variable in time and space and should be investigated in more detail. Interactions between soil temperature and soil moisture in SOC decomposition are known to be complex (Conant et al., 2011; Moyano et al., 2013; Sierra et al., 2015). A sensitivity analysis performed on these two boundary conditions showed that the model was not very sensitive to soil temperature and soil moisture (Fig. S3), but the real effect of these two parameters on SOC dynamics under agroforestry systems should be specifically investigated in future studies. Despite these simplifying assumptions on similarities in microclimate but also on vertical transport between the control and the agroforestry system, the model calibrated to the control plot was able to reproduce SOC stocks in tree rows and alleys and their depth distribution well. This strong validation also revealed that OC inputs were sufficient to explain the differences in SOC stocks at this site. Furthermore, the SOC decomposition rate could also be modified due to an absence of soil tillage in the tree rows (Balesdent et al., 1990) or to an increased aggregate stability (Udawatta et al., 2008) in the topsoil. 


\section{(a) Control plot}
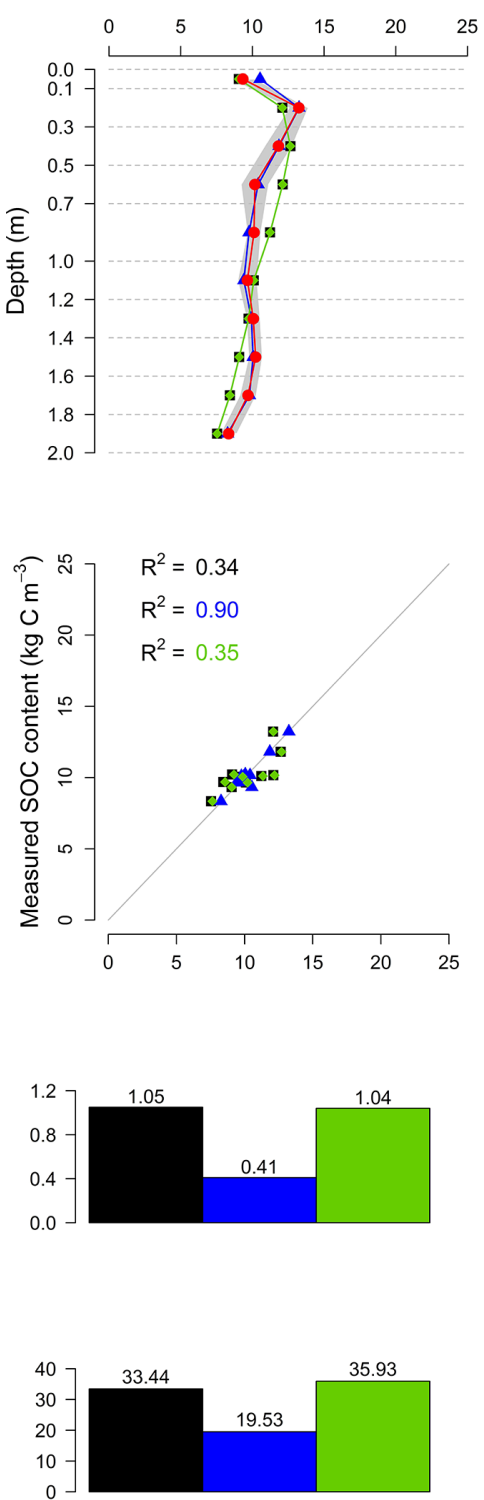

(b) Agroforestry - tree row SOC content $\left(\mathrm{kg} \mathrm{C} \mathrm{m}^{-3}\right)$
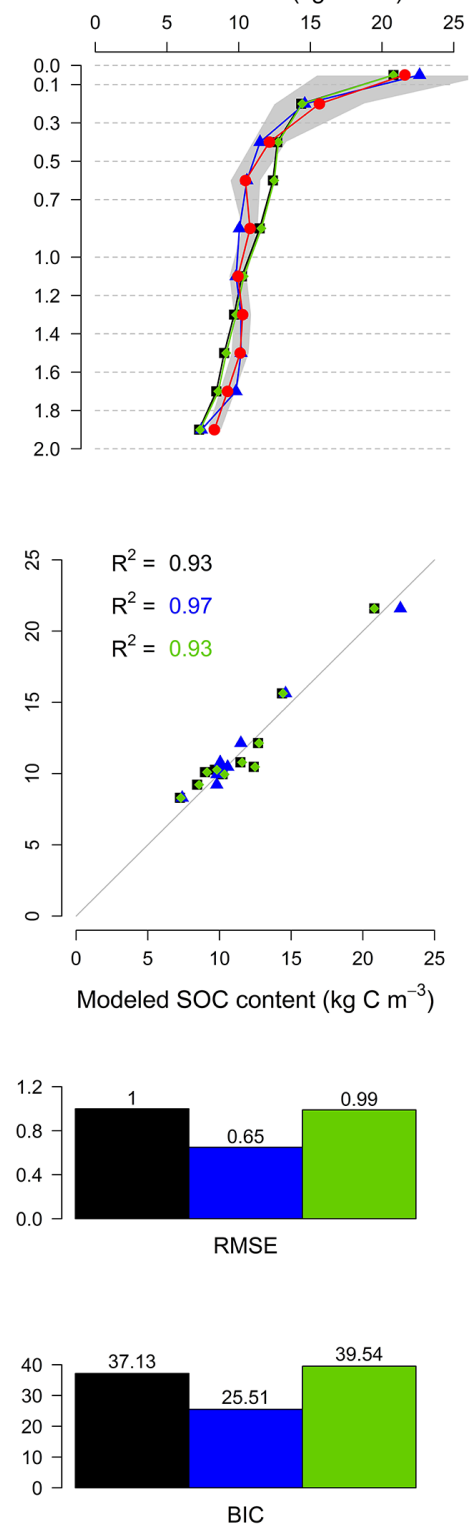

\section{(c) Agroforestry - alley}
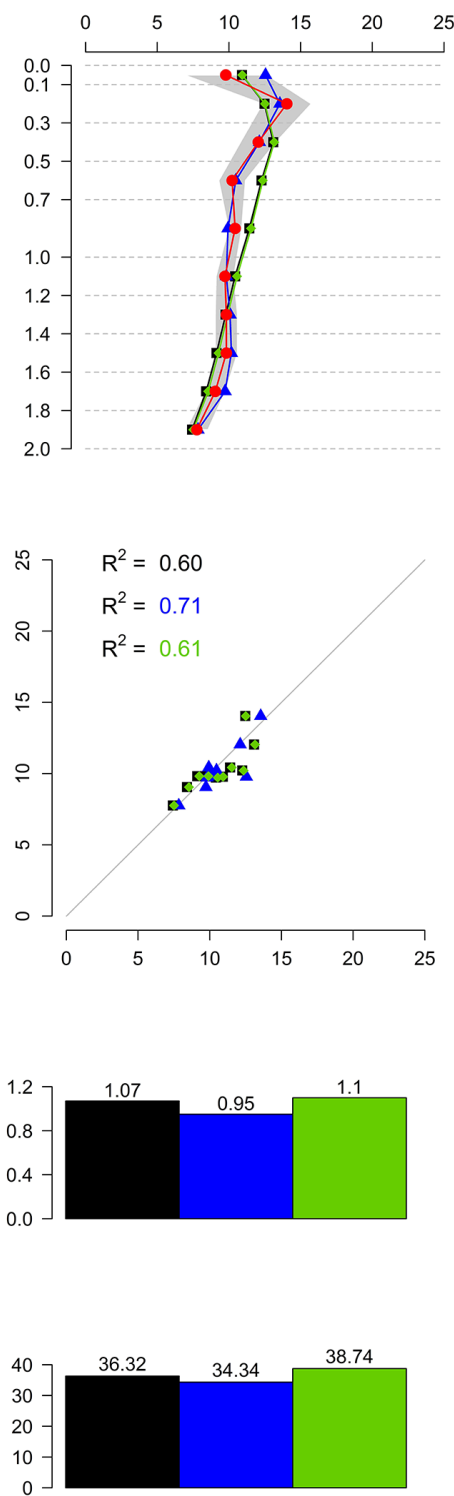

Modeled / two pools - no PE $\Delta$ Modeled / two pools - PE

Modeled / three pools - no PE • Measured

Figure 5. Measured and modeled soil organic carbon contents $\left(\mathrm{kg} \mathrm{Cm}^{-3}\right)$ in an agricultural control plot and in an 18-year-old silvoarable system with a two-pool model without the priming effect (no PE), with a two-pool model with the priming effect (PE), and with a three-pool model without PE. Gray shaded bands represent SDs of measured SOC stocks ( $n=93$ in the control, $n=40$ in the tree rows, and $n=60$ in the alleys).

\subsection{Representation of SOC spatial heterogeneity in agroforestry systems}

The lateral spatial heterogeneity of SOC stocks in the agroforestry plot was well described by the two-pool model including the priming effect, with higher SOC stocks in the tree row topsoil than in the alleys. The model treated the car- bon from the tree row herbaceous litter as an input to the upper layer of the mineral soil, in the same way as inputs by roots. The introduction of nitrogen in the model could be further tested in order to take into account a lower carbon use efficiency due to a lack of nutrients for microbial growth in this litter. The strong SOC gradient observed in the topsoil in tree rows compared to the resolution used could 

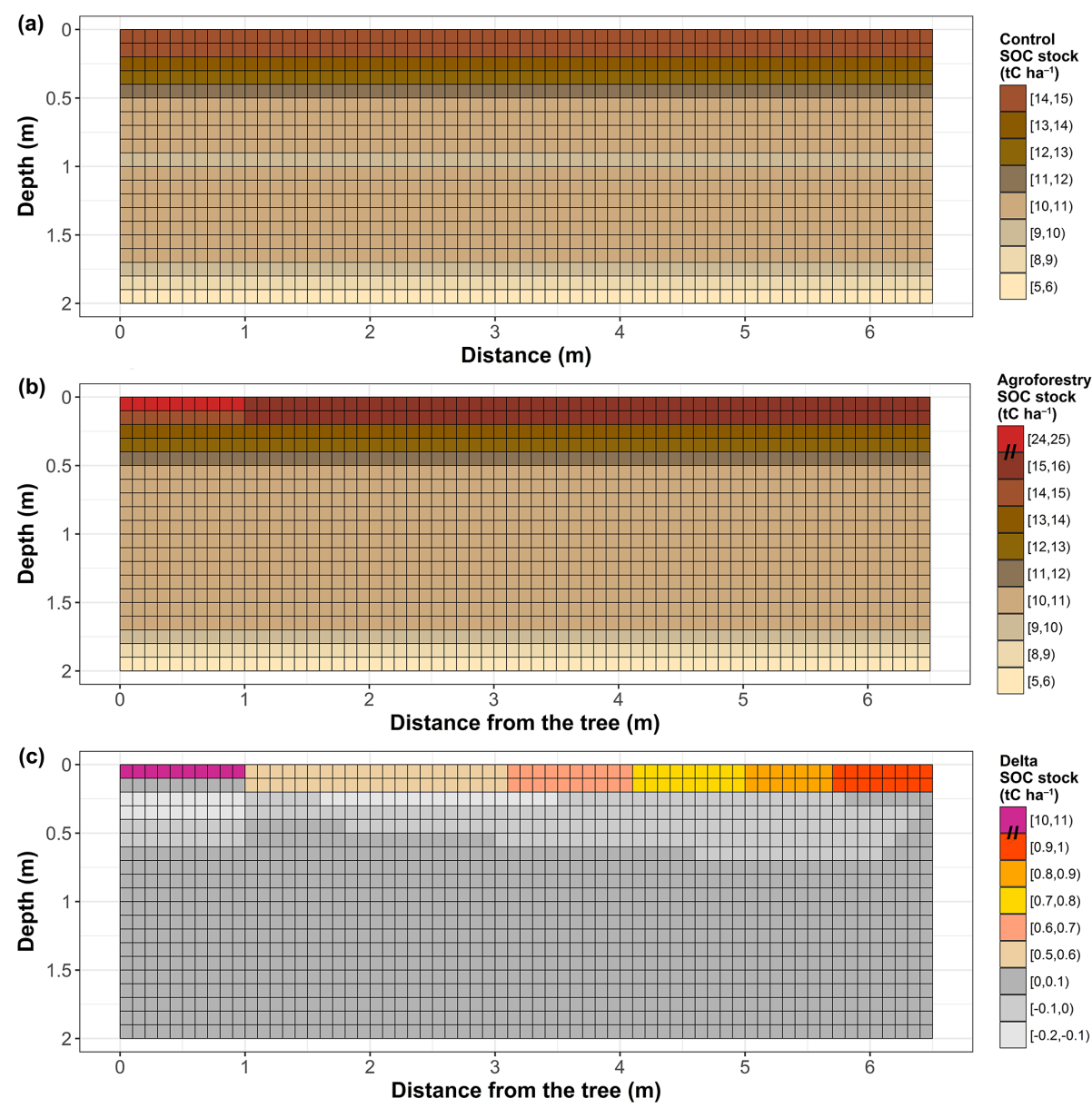

Figure 6. Spatial distribution of control SOC stocks (a), agroforestry SOC stocks (b), and additional SOC storage (tCha $\left.{ }^{-1}\right)$ in an 18 -year-old silvoarable system compared to an agricultural control plot and represented by the two-pool model with the priming effect (c). The scales used in (b) and (c) are not continuous due to the large stocks predicted by the model in the top layer in the tree row.

lead to numerical errors. We therefore tested a finer grid resolution and the results were very similar, suggesting some robustness of the model. For all models, SOC stocks were better described in the tree rows than in the alleys. In the alleys, the spatial distribution of organic inputs is more complex and thus more difficult to model. The tree root system is influenced by soil tillage and competition with the crop roots, and thus the highest tree fine root density is not observed in the topsoil but in the $0.3-0.5 \mathrm{~m}$ soil layer (Cardinael et al., 2015a). In the model, we were not able to represent this specific tree root pattern with commonly used mathematical functions, and tree root profiles were modeled by default using a decreasing exponential. Indeed, piecewise linear functions introduce threshold effects not desirable for transport mechanisms, especially diffusion. This simplification could partly explain the model overestimation of SOC stocks in the $0.0-0.1 \mathrm{~m}$ layer of the alleys compared to observed data. This result suggests that it could be useful to couple the CARBOSAF model with a model describing root architecture and root growth (Dunbabin et al., 2013; Dupuy et al., 2010), for instance using voxel automata (Mulia et al., 2010). Moreover, the model described a slight increase in SOC stocks in the middle of the alleys rather than close to the trees in the alleys. This could be explained by the linear equation used to describe the crop yield as a function of the distance from the trees, leading to an overestimation of the crop yield reduction close to the trees. It could also be explained by the formalism used to model leaf litter distribution in the plot. We considered a homogeneous distribution of leaf inputs in the agroforestry plot, which was the case in the last years but probably not in the first years of the tree growth during which leaves might be more concentrated close to the trees (Thevathasan and Gordon, 1997).

The two-pool model with the priming effect also represented a slight SOC storage in the agroforestry plot below $1.0 \mathrm{~m}$ of depth, but it was not observed in the field. This could be linked to an overestimation of $\mathrm{C}$ input from tree fine root mortality. Indeed, a constant root turnover was considered along the soil profile, but several authors reported a decrease in the root turnover with increasing soil depth 
(Germon et al., 2016; Hendrick and Pregitzer, 1996; Joslin et al., 2006). However, the sensitivity analysis showed that the model was not sensitive to this parameter (Fig. S3 in the Supplement).

\subsection{Vertical representation of SOC profiles in models}

The best model to represent SOC profiles considered the priming effect. This process can act in two different ways on the shape of SOC profiles. It has a direct effect on SOC mineralization and therefore modulates the amount of SOC in each soil layer, creating different SOC gradients. This indirectly affects the mechanisms of $\mathrm{C}$ transport within the soil profile, as shown by a modification of transport coefficients in the case of the priming effect (Table 5). Contrary to what was shown by Cardinael et al. (2015c) in long-term bare fallows receiving contrasted organic amendments, the addition of another SOC pool could not surpass the inclusion of the priming effect in terms of model performance. Together with Wutzler and Reichstein (2013) and Guenet et al. (2016), this study therefore suggests that implementing the priming effect into SOC models would improve model performances, especially when modeling deep SOC profiles.

We considered here the same transport coefficients for the FOC and HSOC pools, but the quality and the size of OC particles are different, potentially leading to various movements in the soil by water fluxes or fauna activity (Lavelle, 1997). Moreover, we considered identical transport parameters in the agroforestry and in the control plot, but the presence of trees could modify soil structure, soil water fluxes (Anderson et al., 2009), and fauna activity (Price and Gordon, 1999). However, the model was not very sensitive to these parameters (Fig. S3). Further study could investigate the role of different transport coefficients in the description of SOC profiles.

\subsection{Higher OC inputs or a different quality of OC?}

The introduction of trees in an agricultural field not only modifies the amount of litter residues, but also their quality. Tree leaves, tree roots, and the herbaceous vegetation from the tree row have different $\mathrm{C}: \mathrm{N}$ ratios, lignin, and cellulose contents than the crop residues. Recent studies showed that plant diversity had a positive impact on SOC storage (Lange et al., 2015; Steinbeiss et al., 2008). One of the hypotheses proposed by the authors is that diverse plant communities result in more active, more abundant, and more diverse microbial communities, increasing microbial products that can potentially be stabilized. In our model, litter quality is not related to different SOC pools but is implicitly taken into account in the FOC decomposition rate, which is weighted by the respective contribution from the different types of OC inputs. To test this, we performed a model run considering that all OC inputs in the agroforestry plot were crop inputs (all FOC decomposition rates equaled the wheat decomposition rate), but the results were not significantly different from the one presented here. Hence, we considered that changes in litter quality in the agroforestry plot did not significantly influence SOC decomposition rates.

\subsection{Possible limitation of SOC storage by the priming effect}

Our modeling results suggested that the priming effect could considerably reduce the capacity of soils to store organic carbon. Our study showed that the increase in SOC stocks was not proportional to OC inputs, especially at depth. This result has often been observed in Free-Air $\mathrm{CO}_{2}$ Enrichment (FACE) experiments. In these experiments, productivity is usually increased due to $\mathrm{CO}_{2}$ fertilization, but several authors also reported an increase in SOC decomposition not linearly linked to the productivity increase (van Groenigen et al., 2014; Sulman et al., 2014). In a long-term FACE experiment, Carney et al. (2007) also found that SOC decreased due to the priming effect, offsetting $52 \%$ of additional carbon accumulated in aboveground and coarse root biomass. The priming effect intensity also relies on nutrient availability (Zhang et al., 2013). In agroforestry systems, tree roots can intercept leached nitrate below the crop rooting zone (Andrianarisoa et al., 2016), reducing nutrient availability. This beneficial ecosystem service could indirectly increase the priming effect intensity in deep soil layers.

The formalism used here to simulate the priming effect assumes that there is no mineralization of SOC in the absence of fresh OC inputs (no basal respiration). This is a strong hypothesis, but this situation never occurs since the FOC pool is never empty (data not shown). In the alleys and below the maximum rooting depth of crops, there are no direct inputs of FOC, but OC is transported in these deep layers due to transport mechanisms. However, further studies could explore the impact of the priming effect formalism on the estimation of its intensity by using explicit microbial biomass, for instance (Blagodatsky et al., 2010; Perveen et al., 2014).

Finally, root exudates were not quantified in this study. Several authors showed that they could induce strong priming effects (Bengtson et al., 2012; Keiluweit et al., 2015), but root exudates are also a source of labile carbon, potentially contributing to stable SOC (Cotrufo et al., 2013). These opposing effects of root exudates on SOC should be further investigated, especially concerning the deep roots in agroforestry systems.

\section{Conclusions}

We proposed the first model that simulates soil organic carbon dynamics in agroforestry accounting for both the whole soil profile and the lateral spatial heterogeneity in agroforestry plots. The two-pool model with the priming effect described reasonably well the measured SOC stocks after 
18 years of agroforestry and SOC distributions with depth. It showed that the increased inputs of fresh biomass to soil in the agroforestry system explained the observed additional SOC storage and suggested the priming effect as a process controlling SOC stocks in the presence of trees. This study points out processes that may be modified by deep-rooted trees and deserve further study given their potential effects on SOC dynamics, such as additional inputs of $\mathrm{C}$ as root exudates or altered soil structure leading to modified SOC transport rates.

\section{Information about the Supplement}

The Supplement includes the walnut tree fine root biomass (Table S1 in the Supplement), the covariance matrices $P_{\mathrm{b}}$ of optimized parameters (Table S2 in the Supplement), the different model performances (Table S3 in the Supplement), the potential SOC decomposition rate as a function of soil depth (Fig. S1 in the Supplement), the correlation matrices of optimized parameters (Fig. S2 in the Supplement), and a sensitivity analysis of the model (Fig. S3 in the Supplement).

Data availability. The data and the model are freely available upon request and can be obtained by contacting the author (remi.cardinael@cirad.fr).

\section{The Supplement related to this article is available online at https://doi.org/10.5194/bg-15-297-2018-supplement.}

Competing interests. The authors declare that they have no conflict of interest.

Acknowledgements. This study was financed by the French Environment and Energy Management Agency (ADEME), following a call for proposals as part of the REACCTIF program (Research on Climate Change Mitigation in Agriculture and Forestry). This work was part of the funded project AGRIPSOL (Agroforestry for Soil Protection; 1260C0042) coordinated by Agroof. Rémi Cardinael was supported both by ADEME and by La Fondation de France. We thank the farmer, Mr. Breton, who allowed us to sample in his field. We are very grateful to our colleagues for their work in the field since the tree planting, especially Jean-François Bourdoncle, Myriam Dauzat, Lydie Dufour, Jonathan Mineau, Alain Sellier, and Benoit Suard. We thank the colleagues and students who helped us with measurements in the field or in the laboratory, especially Daniel Billiou, Cyril Girardin, Patricia Mahafaka, Agnès Martin, Valérie Pouteau, Alexandre Rosa, and Manon Villeneuve. Finally, we would like to thank Jérôme Balesdent, Pierre Barré, and Philippe Peylin for their valuable comments on the modeling part of this work.
Edited by: Andreas Ibrom

Reviewed by: Thomas Wutzler and one anonymous referee

\section{References}

Ahrens, B., Braakhekke, M. C., Guggenberger, G., Schrumpf, M., and Reichstein, M.: Contribution of sorption, DOC transport and microbial interactions to the ${ }^{14} \mathrm{C}$ age of a soil organic carbon profile: Insights from a calibrated process model, Soil Biol. Biochem., 88, 390-402, 2015.

Albrecht, A. and Kandji, S. T.: Carbon sequestration in tropical agroforestry systems, Agr. Ecosyst. Environ., 99, 15-27, 2003.

Anderson, S. H., Udawatta, R. P., Seobi, T., and Garrett, H. E.: Soil water content and infiltration in agroforestry buffer strips, Agroforest. Syst., 75, 5-16, 2009.

Andrianarisoa, K., Dufour, L., Bienaime, S., Zeller, B., and Dupraz, C.: The introduction of hybrid walnut trees (Juglans nigra $\times$ regia $\mathrm{cv}$. NG23) into cropland reduces soil mineral $\mathrm{N}$ content in autumn in southern France, Agroforest. Syst., 90, 193205, 2016.

Baisden, W. T. and Parfitt, R. L.: Bomb ${ }^{14} \mathrm{C}$ enrichment indicates decadal C pool in deep soil?, Biogeochemistry, 85, 59-68, 2007.

Baisden, W. T., Amundson, R., Brenner, D. L., Cook, A. C., Kendall, C., and Harden, J. W.: A multiisotope $\mathrm{C}$ and N modeling analysis of soil organic matter turnover and transport as a function of soil depth in a California annual grassland soil chronosequence, Global Biogeochem. Cy., 16, 82-1-82-26, 2002.

Balandier, P. and Dupraz, C.: Growth of widely spaced trees. A case study from young agroforestry plantations in France, Agroforest. Syst., 43, 151-167, 1999.

Balesdent, J., Mariotti, A., and Boisgontier, D.: Effect of tillage on soil organic carbon mineralization estimated from ${ }^{13} \mathrm{C}$ abundance in maize fields, J. Soil Sci., 41, 587-596, 1990.

Bambrick, A. D., Whalen, J. K., Bradley, R. L., Cogliastro, A., Gordon, A. M., Olivier, A., and Thevathasan, N. V.: Spatial heterogeneity of soil organic carbon in tree-based intercropping systems in Quebec and Ontario, Canada, Agroforest. Syst., 79, 343353, 2010.

Bengtson, P., Barker, J., and Grayston, S. J.: Evidence of a strong coupling between root exudation, $\mathrm{C}$ and $\mathrm{N}$ availability, and stimulated SOM decomposition caused by rhizosphere priming effects, Ecol. Evol., 2, 1843-1852, 2012.

Blagodatsky, S., Blagodatskaya, E., Yuyukina, T., and Kuzyakov, Y.: Model of apparent and real priming effects: linking microbial activity with soil organic matter decomposition, Soil Biol. Biochem., 42, 1275-1283, 2010.

Braakhekke, M. C., Beer, C., Hoosbeek, M. R., Reichstein, M., Kruijt, B., Schrumpf, M., and Kabat, P.: SOMPROF: a vertically explicit soil organic matter model, Ecol. Model., 222, 17121730, 2011.

Bruun, S., Christensen, B. T., Thomsen, I. K., Jensen, E. S., and Jensen, L. S.: Modeling vertical movement of organic matter in a soil incubated for 41 years with ${ }^{14} \mathrm{C}$ labeled straw, Soil Biol. Biochem., 39, 368-371, 2007.

Burgess, P. J., Incoll, L. D., Corry, D. T., Beaton, A., and Hart, B. J.: Poplar (Populus spp.) growth and crop yields in a silvoarable experiment at three lowland sites in England, Agroforest. Syst., 63, 157-169, 2004. 
Cardinael, R., Mao, Z., Prieto, I., Stokes, A., Dupraz, C., Kim, J. H., and Jourdan, C.: Competition with winter crops induces deeper rooting of walnut trees in a Mediterranean alley cropping agroforestry system, Plant Soil, 391, 219-235, 2015a.

Cardinael, R., Chevallier, T., Barthès, B. G., Saby, N. P. A., Parent, T., Dupraz, C., Bernoux, M., and Chenu, C.: Impact of alley cropping agroforestry on stocks, forms and spatial distribution of soil organic carbon - a case study in a Mediterranean context, Geoderma, 259-260, 288-299, 2015b.

Cardinael, R., Eglin, T., Guenet, B., Neill, C., Houot, S., and Chenu, C.: Is priming effect a significant process for long-term SOC dynamics? Analysis of a 52-years old experiment, Biogeochemistry, 123, 203-219, 2015c.

Cardinael, R., Chevallier, T., Cambou, A., Béral, C., Barthès, B. G., Dupraz, C., Durand, C., Kouakoua, E., and Chenu, C.: Increased soil organic carbon stocks under agroforestry: a survey of six different sites in France, Agr. Ecosyst. Environ., 236, 243-255, 2017.

Carney, K. M., Hungate, B. A., Drake, B. G., and Megonigal, J. P.: Altered soil microbial community at elevated $\mathrm{CO}_{2}$ leads to loss of soil carbon, P. Natl. Acad. Sci. USA, 104, 4990-4995, 2007.

Charbonnier, F., le Maire, G., Dreyer, E., Casanoves, F., Christina, M., Dauzat, J., Eitel, J. U. H., Vaast, P., Vierling, L. A., and Roupsard, O.: Competition for light in heterogeneous canopies: application of MAESTRA to a coffee (Coffea arabica L.) agroforestry system, Agr. Forest Meteorol., 181, 152-169, 2013.

Chaudhry, A. K., Khan, G. S., Siddiqui, M. T., Akhtar, M., and Aslam, Z.: Effect of arable crops on the growth of poplar (Populus deltoides) tree in agroforestry system, Pak. J. Agr. Sci., 40, 82-85, 2003.

Chifflot, V., Bertoni, G., Cabanettes, A., and Gavaland, A.: Beneficial effects of intercropping on the growth and nitrogen status of young wild cherry and hybrid walnut trees, Agroforest. Syst., 66, 13-21, 2006.

Clinch, R. L., Thevathasan, N. V., Gordon, A. M., Volk, T. A., and Sidders, D.: Biophysical interactions in a short rotation willow intercropping system in southern Ontario, Canada, Agr. Ecosyst. Environ., 131, 61-69, 2009.

Conant, R. T., Ryan, M. G., Ågren, G. I., Birge, H. E., Davidson, E. A., Eliasson, P. E., Evans, S. E., Frey, S. D., Giardina, C. P., Hopkins, F. M., Hyvönen, R., Kirschbaum, M. U. F., Lavallee, J. M., Leifeld, J., Parton, W. J., Megan Steinweg, J., Wallenstein, M. D., Martin Wetterstedt, J. Å., and Bradford, M. A.: Temperature and soil organic matter decomposition rates - synthesis of current knowledge and a way forward, Glob. Change Biol., 17, 3392-3404, 2011.

Cotrufo, M. F., Wallenstein, M. D., Boot, C. M., Denef, K., and Paul, E.: The Microbial Efficiency-Matrix Stabilization (MEMS) framework integrates plant litter decomposition with soil organic matter stabilization: do labile plant inputs form stable soil organic matter?, Glob. Change Biol., 19, 988-95, 2013.

Davidson, E. A. and Janssens, I. A.: Temperature sensitivity of soil carbon decomposition and feedbacks to climate change, Nature, 440, 165-173, 2006.

Dimassi, B., Cohan, J.-P., Labreuche, J., and Mary, B.: Changes in soil carbon and nitrogen following tillage conversion in a longterm experiment in Northern France, Agr. Ecosyst. Environ., 169, 12-20, 2013.
Dubbert, M., Mosena, A., Piayda, A., Cuntz, M., Correia, A. C., Pereira, J. S., and Werner, C.: Influence of tree cover on herbaceous layer development and carbon and water fluxes in a Portuguese cork-oak woodland, Acta Oecol., 59, 35-45, 2014.

Dufour, L., Metay, A., Talbot, G., and Dupraz, C.: Assessing light competition for cereal production in temperate agroforestry systems using experimentation and crop modelling, J. Agron. Crop Sci., 199, 217-227, 2013.

Dunbabin, V. M., Postma, J. A., Schnepf, A., Pagès, L., Javaux, M., Wu, L., Leitner, D., Chen, Y. L., Rengel, Z., and Diggle, A. J.: Modelling root-soil interactions using three-dimensional models of root growth, architecture and function, Plant Soil, 372, 93124, 2013.

Dupuy, L., Gregory, P. J., and Bengough, A. G.: Root growth models: towards a new generation of continuous approaches, J. Exp. Bot., 61, 2131-2143, 2010.

Duursma, R. A. and Medlyn, B. E.: MAESPA: a model to study interactions between water limitation, environmental drivers and vegetation function at tree and stand levels, with an example application to $\left[\mathrm{CO}_{2}\right] \times$ drought interactions, Geosci. Model Dev., 5, 919-940, https://doi.org/10.5194/gmd-5-919-2012, 2012.

Eilers, K. G., Debenport, S., Anderson, S., and Fierer, N.: Digging deeper to find unique microbial communities: The strong effect of depth on the structure of bacterial and archaeal communities in soil, Soil Biol. Biochem., 50, 58-65, 2012.

Eissenstat, D. M. and Yanai, R. D.: The ecology of root lifespan, Adv. Ecol. Res., 27, 1-60, 1997.

Ellert, B. H. and Bettany, J. R.: Calculation of organic matter and nutrients stored in soils under contrasting management regimes, Can. J. Soil Sci., 75, 529-538, 1995.

Elzein, A. and Balesdent, J.: Mechanistic simulation of vertical distribution of carbon concentrations and residence times in soils, Soil Sci. Soc. Am. J., 59, 1328-1335, 1995.

Fierer, N., Schimel, J. P., and Holden, P. A.: Variations in microbial community composition through two soil depth profiles, Soil Biol. Biochem., 35, 167-176, 2003.

Fontaine, S., Barot, S., Barré, P., Bdioui, N., Mary, B., and Rumpel, C.: Stability of organic carbon in deep soil layers controlled by fresh carbon supply, Nature, 450, 277-281, 2007.

Germon, A., Cardinael, R., Prieto, I., Mao, Z., Kim, J. H., Stokes, A., Dupraz, C., Laclau, J.-P., and Jourdan, C.: Unexpected phenology and lifespan of shallow and deep fine roots of walnut trees grown in a silvoarable Mediterranean agroforestry system, Plant Soil, 401, 409-426, 2016.

Graves, A. R., Burgess, P. J., Palma, J. H. N., Herzog, F., Moreno, G., Bertomeu, M., Dupraz, C., Liagre, F., Keesman, K., van der Werf, W., de Nooy, a. K., and van den Briel, J. P.: Development and application of bio-economic modelling to compare silvoarable, arable, and forestry systems in three European countries, Ecol. Eng., 29, 434-449, 2007.

Graves, A. R., Burgess, P. J., Palma, J., Keesman, K. J., van der Werf, W., Dupraz, C., van Keulen, H., Herzog, F., and Mayus, M.: Implementation and calibration of the parametersparse Yield-SAFE model to predict production and land equivalent ratio in mixed tree and crop systems under two contrasting production situations in Europe, Ecol. Model., 221, 1744-1756, 2010.

Guenet, B., Eglin, T., Vasilyeva, N., Peylin, P., Ciais, P., and Chenu, C.: The relative importance of decomposition and trans- 
port mechanisms in accounting for soil organic carbon profiles, Biogeosciences, 10, 2379-2392, https://doi.org/10.5194/bg-102379-2013, 2013.

Guenet, B., Moyano, F. E., Peylin, P., Ciais, P., and Janssens, I. A.: Towards a representation of priming on soil carbon decomposition in the global land biosphere model ORCHIDEE (version 1.9.5.2), Geosci. Model Dev., 9, 841-855, https://doi.org/10.5194/gmd-9-841-2016, 2016.

Haile, S. G., Nair, V. D., and Nair, P. K. R.: Contribution of trees to carbon storage in soils of silvopastoral systems in Florida, USA, Glob. Change Biol., 16, 427-438, 2010.

Hendrick, R. L. and Pregitzer, K. S.: Temporal and depth-related patterns of fine root dynamics in northern hardwood forests, J. Ecol., 84, 167-176, 1996.

Howlett, D. S., Moreno, G., Mosquera Losada, M. R., Nair, P. K. R., and Nair, V. D.: Soil carbon storage as influenced by tree cover in the Dehesa cork oak silvopasture of central-western Spain, J. Environ. Monitor., 13, 1897-904, 2011.

Ilstedt, U., Bargués Tobella, A., Bazié, H. R., Bayala, J., Verbeeten, E., Nyberg, G., Sanou, J., Benegas, L., Murdiyarso, D., Laudon, H., Sheil, D., and Malmer, A.: Intermediate tree cover can maximize groundwater recharge in the seasonally dry tropics, Sci. Rep.-UK, 6, 1-12, https://doi.org/10.1038/srep21930, 2016.

IUSS Working Group WRB: World Reference Base for Soil Resources 2006, first update 2007. World Soil Resources Reports No. 103, FAO, Rome, 2007.

Jobbagy, E. G. and Jackson, R. B.: The vertical distribution of soil organic carbon and its relation to climate and vegetation, Ecol. Appl., 10, 423-436, 2000.

Joslin, J. D., Gaudinski, J. B., Torn, M. S., Riley, W. J., and Hanson, P. J.: Fine-root turnover patterns and their relationship to root diameter and soil depth in a ${ }^{14} \mathrm{C}$-labeled hardwood forest, New Phytol., 172, 523-535, 2006.

Kätterer, T., Bolinder, M. A., Andrén, O., Kirchmann, H., and Menichetti, L.: Roots contribute more to refractory soil organic matter than above-ground crop residues, as revealed by a longterm field experiment, Agr. Ecosyst. Environ., 141, 184-192, 2011.

Keiluweit, M., Bougoure, J. J., Nico, P. S., Pett-Ridge, J., Weber, P. K., and Kleber, M.: Mineral protection of soil carbon counteracted by root exudates, Nat. Clim. Chang, 5, 588-595, 2015.

Kim, D.-G., Kirschbaum, M. U. F., and Beedy, T. L.: Carbon sequestration and net emissions of $\mathrm{CH}_{4}$ and $\mathrm{N}_{2} \mathrm{O}$ under agroforestry: Synthesizing available data and suggestions for future studies, Agr. Ecosyst. Environ., 226, 65-78, 2016.

Koarashi, J., Hockaday, W. C., Masiello, C. A., and Trumbore, S. E.: Dynamics of decadally cycling carbon in subsurface soils, J. Geophys. Res., 117, 1-13, 2012.

Koven, C. D., Riley, W. J., Subin, Z. M., Tang, J. Y., Torn, M. S., Collins, W. D., Bonan, G. B., Lawrence, D. M., and Swenson, S. C.: The effect of vertically resolved soil biogeochemistry and alternate soil $\mathrm{C}$ and $\mathrm{N}$ models on C dynamics of CLM4, Biogeosciences, 10, 7109-7131, https://doi.org/10.5194/bg-107109-2013, 2013.

Lange, M., Eisenhauer, N., Sierra, C. A., Bessler, H., Engels, C., Griffiths, R. I., Mellado-Vázquez, P. G., Malik, A. A., Roy, J., Scheu, S., Steinbeiss, S., Thomson, B. C., Trum- bore, S. E., and Gleixner, G.: Plant diversity increases soil microbial activity and soil carbon storage, Nat. Commun., 6, 1-8, https://doi.org/10.1038/ncomms7707, 2015.

Lavelle, P.: Faunal Activities and Soil Processes: Adaptative Strategy that Determine Ecosystem Function, Amsterdam, The Netherlands, Elsevier, 1997.

Li, F., Meng, P., Fu, D., and Wang, B.: Light distribution, photosynthetic rate and yield in a Paulownia-wheat intercropping system in China, Agroforest. Syst., 74, 163-172, 2008.

Lorenz, K. and Lal, R.: Soil organic carbon sequestration in agroforestry systems. A review, Agron. Sustain. Dev., 34, 443-454, 2014.

Luedeling, E., Smethurst, P. J., Baudron, F., Bayala, J., Huth, N. I., van Noordwijk, M., Ong, C. K., Mulia, R., Lusiana, B., Muthuri, C., and Sinclair, F. L.: Field-scale modeling of tree-crop interactions: challenges and development needs, Agric. Syst., 142, 51-69, 2016.

Mead, R. and Willey, R. W.: The concept of a "land equivalent ratio" and advantages in yields from intercropping, Exp. Agr., 16, 217228, 1980.

Moreno, G., Obrador, J. J., Cubera, E., and Dupraz, C.: Fine root distribution in Dehesas of central-western Spain, Plant Soil, 277, 153-162, 2005.

Moyano, F. E., Vasilyeva, N., Bouckaert, L., Cook, F., Craine, J., Curiel Yuste, J., Don, A., Epron, D., Formanek, P., Franzluebbers, A., Ilstedt, U., Kätterer, T., Orchard, V., Reichstein, M., Rey, A., Ruamps, L., Subke, J.-A., Thomsen, I. K., and Chenu, C.: The moisture response of soil heterotrophic respiration: interaction with soil properties, Biogeosciences, 9, 1173-1182, https://doi.org/10.5194/bg-9-1173-2012, 2012.

Moyano, F. E., Manzoni, S., and Chenu, C.: Responses of soil heterotrophic respiration to moisture availability: An exploration of processes and models, Soil Biol. Biochem., 59, 72-85, 2013.

Mulia, R. and Dupraz, C.: Unusual fine root distributions of two deciduous tree species in southern France: What consequences for modelling of tree root dynamics?, Plant Soil, 281, 71-85, 2006.

Mulia, R., Dupraz, C., and van Noordwijk, M.: Reconciling root plasticity and architectural ground rules in tree root growth models with voxel automata, Plant Soil, 337, 77-92, 2010.

Nair, P. K.: An Introduction to Agroforestry, Kluwer Academic Publishers, Dordrecht, The Netherlands, 1993.

Nair, P. K. R.: Classification of agroforestry systems, Agrofor. Syst., 3, 97-128, 1985.

Odhiambo, H. O., Ong, C. K., Deans, J. D., Wilson, J., Khan, A. A. H., and Sprent, J. I.: Roots, soil water and crop yield: Tree crop interactions in a semi-arid agroforestry system in Kenya, Plant Soil, 235, 221-233, 2001.

Oelbermann, M. and Voroney, R. P.: And evaluation of the century model to predict soil organic carbon: examples from Costa Rica and Canada, Agrofor. Syst., 82, 37-50, 2011.

Oelbermann, M., Voroney, R. P., and Gordon, A. M.: Carbon sequestration in tropical and temperate agroforestry systems: a review with examples from Costa Rica and southern Canada, Agr. Ecosyst. Environ., 104, 359-377, 2004.

Oelbermann, M., Voroney, R. P., Thevathasan, N. V., Gordon, A. M., Kass, D. C. L., and Schlönvoigt, A. M.: Soil carbon dynamics and residue stabilization in a Costa Rican and southern Canadian alley cropping system, Agroforest. Syst., 68, 27-36, 2006. 
Ong, C. K. and Leakey, R. R. B.: Why tree-crop interactions in agroforestry appear at odds with tree-grass interactions in tropical savannahs, Agroforest. Syst., 45, 109-129, 1999.

Parton, W. J., Schimel, D. S., Cole, C. V., and Ojima, D. S.: Analysis of factors controlling soil organic matter levels in great plains grasslands, Soil Sci. Soc. Am. J., 51, 1173-1179, 1987.

Peichl, M., Thevathasan, N. V, Gordon, A. M., Huss, J., and Abohassan, R. A.: Carbon sequestration potentials in temperate treebased intercropping systems, southern Ontario, Canada, Agroforest. Syst., 66, 243-257, 2006.

Perveen, N., Barot, S., Alvarez, G., Klumpp, K., Martin, R., Rapaport, A., Herfurth, D., Louault, F., and Fontaine, S.: Priming effect and microbial diversity in ecosystem functioning and response to global change: a modeling approach using the SYMPHONY model, Glob. Change Biol., 20, 1174-1190, 2014.

Price, G. W. and Gordon, A. M.: Spatial and temporal distribution of earthworms in a temperate intercropping system in southern Ontario, Canada, Agroforest. Syst., 44, 141-149, 1999.

Prieto, I., Roumet, C., Cardinael, R., Kim, J., Maeght, J.-L., Mao, Z., Portillo, N., Thammahacksa, C., Dupraz, C., Jourdan, C., Pierret, A., Roupsard, O., and Stokes, A.: Root functional parameters along a land-use gradient: evidence of a community-level economics spectrum, J. Ecol., 103, 361-373, 2015.

Prieto, I., Stokes, A., and Roumet, C.: Root functional parameters predict fine root decomposability at the community level, J. Ecol., 104, 725-733, 2016.

R Development Core Team: R: A Language and Environment for Statistical Computing, Vienna, Austria, the R Foundation for Statistical Computing, 2013.

Rasse, D. P., Mulder, J., Moni, C., and Chenu, C.: Carbon turnover kinetics with depth in a French loamy soil, Soil Sci. Soc. Am. J., 70, 2097-2105, 2006.

Salomé, C., Nunan, N., Pouteau, V., Lerch, T. Z., and Chenu, C.: Carbon dynamics in topsoil and in subsoil may be controlled by different regulatory mechanisms, Glob. Change Biol., 16, 416426, 2010

Santaren, D., Peylin, P., Viovy, N., and Ciais, P.: Optimizing a process-based ecosystem model with eddy-covariance flux measurements: a pine forest in southern France, Global Biogeochem. Cy., 21, 1-15, 2007.

Schwarz, G.: Estimating dimension of a model, Ann. Stat., 6, 461464, 1978

Shahzad, T., Chenu, C., Genet, P., Barot, S., Perveen, N., Mougin, C., and Fontaine, S.: Contribution of exudates, arbuscular mycorrhizal fungi and litter depositions to the rhizosphere priming effect induced by grassland species, Soil Biol. Biochem., 80, 146-155, 2015.

Sierra, C. A., Trumbore, S. E., Davidson, E. A., Vicca, S., and Janssens, I.: Sensitivity of decomposition rates of soil organic matter with respect to simultaneous changes in temperature and moisture, J. Adv. Model. Earth Sy., 7, 335-356, 2015.

Soetaert, K., Petzoldt, T., and Woodrow Setzer, R.: Solving differential equations in R: package deSolve, J. Stat. Softw., 33, 1-25, 2010.

Somarriba, E.: Revisiting the past: an essay on agroforestry definition, Agroforest. Syst., 19, 233-240, 1992.

Steinbeiss, S., Beßler, H., Engels, C., Temperton, V. M., Buchmann, N., Roscher, C., Kreutziger, Y., Baade, J., Habekost, M., and Gleixner, G.: Plant diversity positively affects short-term soil carbon storage in experimental grasslands, Glob. Change Biol., 14, 2937-2949, 2008.

Sulman, B. N., Phillips, R. P., Oishi, A. C., Shevliakova, E., and Pacala, S. W.: Microbe-driven turnover offsets mineral-mediated storage of soil carbon under elevated $\mathrm{CO}_{2}$, Nat. Clim. Change, 4 , 1099-1102, 2014.

Taghizadeh-Toosi, A., Christensen, B. T., Hutchings, N. J., Vejlin, J., Kätterer, T., Glendining, M., and Olesen, J. E.: C-TOOL: a simple model for simulating whole-profile carbon storage in temperate agricultural soils, Ecol. Model., 292, 11-25, 2014.

Talbot, G.: L'intégration spatiale et temporelle du partage des ressources dans un système agroforestier noyers-céréales: une clef pour en comprendre la productivité?, PhD Dissertation, Université Montpellier II, Montpellier, France, 2011.

Tarantola, A.: Inverse Problem Theory: Methods for Data Fitting and Model Parameter Estimation, Elsevier, the Netherlands, 1987.

Tarantola, A.: Inverse Problem Theory and Methods for Model Parameter Estimation, SIAM, Philadelphia, USA, 2005.

Thevathasan, N. V. and Gordon, A. M.: Poplar leaf biomass distribution and nitrogen dynamics in a poplar-barley intercropped system in southern Ontario, Canada, Agroforest. Syst., 37, 7990, 1997.

Udawatta, R. P., Kremer, R. J., Adamson, B. W., and Anderson, S. H.: Variations in soil aggregate stability and enzyme activities in a temperate agroforestry practice, Appl. Soil Ecol., 39, 153-160, 2008.

van der Werf, W., Keesman, K., Burgess, P., Graves, A., Pilbeam, D., Incoll, L. D., Metselaar, K., Mayus, M., Stappers, R., van Keulen, H., Palma, J., and Dupraz, C.: Yield-SAFE: A parameter-sparse, process-based dynamic model for predicting resource capture, growth, and production in agroforestry systems, Ecol. Eng., 29, 419-433, 2007.

van Groenigen, K. J., Qi, X., Osenberg, C. W., Luo, Y., and Hungate, B. A.: Faster decomposition under increased atmospheric $\mathrm{CO}_{2}$ limits soil carbon storage, Science, 344, 508-509, 2014.

van Noordwijk, M. and Lusiana, B.: WaNuLCAS, a model of water, nutrient and light capture in agroforestry systems, Agrofor. Syst., 43, 217-242, 1999.

Virto, I., Barré, P., Burlot, A., and Chenu, C.: Carbon input differences as the main factor explaining the variability in soil organic $\mathrm{C}$ storage in no-tilled compared to inversion tilled agrosystems, Biogeochemistry, 108, 17-26, 2012.

Wutzler, T. and Reichstein, M.: Colimitation of decomposition by substrate and decomposers - a comparison of model formulations, Biogeosciences, 5, 749-759, https://doi.org/10.5194/bg-5749-2008, 2008.

Wutzler, T. and Reichstein, M.: Priming and substrate quality interactions in soil organic matter models, Biogeosciences, 10, 20892103, https://doi.org/10.5194/bg-10-2089-2013, 2013.

Yin, R. and He, Q.: The spatial and temporal effects of paulownia intercropping: the case of northern China, Agroforest. Syst., 37, 91-109, 1997.

Zhang, W., Wang, X., and Wang, S.: Addition of external organic carbon and native soil organic carbon decomposition: a meta-analysis, PLoS One, 8, 1-6, https://doi.org/10.1371/journal.pone.0054779, 2013 